ARTICLE TYPE

\title{
Synthesis and self-assembly of amphiphilic polymers based on polyoxazoline and vegetable oil derivatives MylèneStemmelen, ${ }^{a}$ Christophe Travelet, ${ }^{b}$ Vincent Lapinte, ${ }^{* a}{ }^{a}$ edouaneBorsali ${ }^{b}$ and Jean-Jacques Robin ${ }^{a}$
}

\author{
Received 10th October 2012, Accepted 21th November 2012 \\ ${ }_{5}$ DOI: 10.1039/c2py20840g
}

\begin{abstract}
The synthesis and self-assembly of amphiphilic polymers based on unsaturated vegetable oils and poly(2-methyl-2-oxazoline)(POx) are reported. Two architectures of lipopolymers were explored starting from fatty methyl esters and raw vegetable oils. These latter were converted into macroinitiators for cationic ring-opening polymerization (CROP) of 2-methyl-2-oxazoline. Firstly, a thiol-ene coupling reaction in the presence of mercaptoethanol under UV irradiation was performed to introduce hydroxyl groups that were further 10 transformed into initiating species used for cationic polymerization. According to this strategy, various lipopoly(2-methyl-2-oxazoline)s (LipoPOx)s with different lipidic/POx ratios were successfully obtained and characterized by ${ }^{1} \mathrm{H}$ NMR, SEC and MALDI-Tof analyses. Finally, the self-organization of the LipoPOx was studied using dynamic light scattering (DLS). Well-shaped nanoparticles were obtained with characteristic radii of 4.3 and $10.2 \mathrm{~nm}$ for the fatty ester- and triglyceride-based lipopolymers, respectively. The latter value is abouttwice the former one due to the higher lipidic fraction of the triglyceride-based polymer that promotes hydrophobic 15 interactions. The relaxation time distributions of both systemswere found to be monomodalindicatingmonodispersecolloidal suspensions.
\end{abstract}

\section{INTRODUCTION}

As a consequence of the depleting of fossil reserves and environmental issues, the use of renewable raw materials is important for sustainable development ${ }^{1}$. The main bio-based raw 20 materials are vegetable oils, polysaccharides, sugars and woods ${ }^{2}$ that are chemically modified for the development of chemicals, polymers $^{2}$, amphiphilic copolymers, composites, blends ${ }^{3}$, plasticizers ${ }^{4}$, and coatings ${ }^{5}$.

Amphiphilic block copolymers are most often composed of 25 hydrophilic blocks covalently linked to hydrophobic ones. Theyhave the ability to self-assemble in bulk or in solution,leading to different soft materials ${ }^{6}$ such as micelles, vesicles ${ }^{7}$, polymersomes ${ }^{8}$, and gels. The peculiar behavior of these copolymers in solution allows their use as surfactants, emulsifiers ${ }^{9}$, drug carriers ${ }^{10}$, etc

30 Bio-based amphiphilic polymers can be either totally natural and made of renewable species for both the hydrophilic and hydrophobic parts (e.g. alkyl polyglycosides ${ }^{11}$, nucleolipids ${ }^{12}$, polysaccharideblock-polypeptide ${ }^{13}$ and oligosaccharide linked to hydrophobized oligosaccharide ${ }^{14}$ ), or partially bio-sourced where one block is from 35 renewable resources. Nowadays, this latter class is being widely developed with the synthesis of diblockcopolymers based on oligosaccharides ${ }^{15}$, peptides ${ }^{16}$ or lipids ${ }^{17}$.

Most vegetable oils are mainly composed of triglycerides, which are also known astriacylglycerols (TAG)s, with long alkyl chains

40 (between 12 and 20 carbons). Vegetable oils and their derivatives (fatty alcohols, esters and acids) have been extensivelyinvestigated for the synthesis of oleochemical surfactants. These surfactants can be made ionic with the introduction of a negatively charged head, typically a sulfonate ${ }^{17}$ or carboxylate group ${ }^{18}$ (sulphonate of a 45 glycerol ester or ester of a sulphatedmethylglucoside). Positively charged heads, typically quaternary ammonium or amphoteric species such as betains, can also be encountered. Moreover nonionic surfactants can be produced by associating lipids with hydrophilic molecules like diethanolamine or with hydrophilic 50 polymers such as poly(ethylene oxide)(PEO) $)^{9,17}$, poly (glycerol) ${ }^{19}$ or some poly(oxazoline)s: (poly(2-ethyl-2-oxazoline) or poly(2methyl-2-oxazoline)). Furthermore, we note that a study ofblockcopolymers based on poly(2-methyl-2-oxazoline) or poly(2-ethyl- 2-oxazoline) as the hydrophilic block and hydrophobic poly(255 oxazoline) synthesized from fatty acidshas been recently reported $^{20}$.

In this work wefocus on the synthesis of amphiphilic polymers composed of a natural lipidic hydrophobic part (a vegetable oil or its derivatives) and a hydrophilic chain based on poly(2-methyl-260 oxazoline), so called LipoPOx. Poly(2-methyl-2-oxazoline)is a more hydrophilic polymer than $\mathrm{PEO}^{21}$ and is used as a building block for various macromolecular architectures ${ }^{22}$. POx exhibits a low toxicity ${ }^{23}$ whereas some recent studies suspected toxicity for PEO resulting in bioaccumulation ${ }^{24}$. Thuspoly(2-methyl-265 oxazoline) appears to be a good alternative to PEO-based polymers $^{25}$. Few synthetic routes in obtaining LipoPOx with various structures have been described in the literature so far. First linear lipopolymers were synthesized using lipidic initiators such as iodoalkyl ${ }^{26}$, alkyl trifluoromethanesulfonate or alkyl tosylate ${ }^{27}$ 70 initiators for the polymerization of MOx (2-methyl-2-oxazoline). Furthermore, multi-step strategies were developed to obtain "pseudo-bicatenar" lipopolymers based either on diacylglycerol or glyceroldiethers. In this case, the synthesis and the use of 1,2didodecanoylpropyl- $p$-toluene sulfonate ${ }^{28}$ or 1,2-O-dioctadecyl-sn75 glyceroltosylate or triflate ${ }^{29}$ as the macroinitiator for the polymerization of MOxcan be one approach. The other pathway consists in the preparation ofpoly(2-methyl-2-oxazoline) and then couplinga lipidic block such as disteaorylphosphatidylethanolamine ${ }^{25 c}$ or1,2-didodecanoylpropyl ${ }^{28}$. ${ }_{80}$ It should also be mention that a complex structure oflipopolymer was previously reported using a modified vegetable oil as the starting initiator for the synthesis of LipoPOx ${ }^{30}$. In this case castor oil was modified with $p$-toluenesulfonyl chloride to initiate the cationic ring-opening polymerization (CROP) of MOx.

${ }_{85}$ As opposed to previous reportedwork in the literature, our strategy was based on the chemical modification of double bonds of the triglycerides without modification of the triacylglycerol structure. The main objective and the novelty of this contribution is the extension of the synthesis of LipoPOx to any unsaturated vegetable 90 oils and to all fatty esters. Our strategy is described in Scheme 1. Following to this route, unsaturated lipids were converted into lipidic alcohols thanks to the addition of 2-mercaptoethanol (ME) 
onto double bonds using the thiol-ene coupling (TEC) reaction. The resulting modified lipids were transformed into initiators for the polymerization of MOx. The strategy was first assessed using methyl oleate and afterwards applied to crude oil. We report here the 5 ability of LipoPOx derived from fatty esters and triglycerides to self-organize in aqueous solution. It is important topoint out that literature reported the self-organization of linear LipoPOx in water ${ }^{31}$ has been previously reported in the literature. In the present study, we were interested in the self-organization of branchedLipoPOx 10 based on crude oil and in the formation of nanoparticles.
5 membranes Spectra/Por ${ }^{\circledR}$ - MWCO 500-1000 were purchased from Spectrum Laboratories, Inc.

\section{Characterization}

Nuclear magnetic resonance (NMR) spectra were recorded on a RMN BrukerAvance I $300 \mathrm{MHz}$ or on a BrukerAvance III $600 \mathrm{MHz}$ 40 spectrometers. Chemical shifts $\left({ }^{1} \mathrm{H}\right.$ NMR) were referenced to the peak of residual $\mathrm{CHCl}_{3}$ at $7.26 \mathrm{ppm}$. Chemical shifts $\left({ }^{13} \mathrm{C} \mathrm{NMR}\right)$ were referenced to $\mathrm{CDCl}_{3}$ at $77 \mathrm{ppm}$.Fourier transform infrared (FTIR) spectra were recorded with a Perkin Elmer Spectrum 100 spectrometer equipped with an attenuated total reflectance (ATR) 45 using a ZnSe crystal. The composition of crude oils was determined by gas chromatography (GC) analysis after conversion of the triglycerides into fatty acids (FA)s and methyl esters. The mixture was analyzed on an Agilent 6890 series using a Supelcowax 10 capillary column (SGE, Courtaboeuf, France): length, $30 \mathrm{~m}$; internal

50 diameter, $0.32 \mathrm{~mm}$; film thickness, $0.25 \mu \mathrm{m}$ and carrier gas: helium at a flow rate of $20 \mathrm{ml} / \mathrm{min}$, splitting ratio: 100 , injector temperature: $250^{\circ} \mathrm{C}$, FID detector temperature: $270^{\circ} \mathrm{C}$. The temperature profile was: $185-240^{\circ} \mathrm{C}$ at $4^{\circ} \mathrm{C} / \mathrm{min}, 225^{\circ} \mathrm{C}$ for $10 \mathrm{~min}$. The HPLC/ESI system consisted of a capillary HPLC system (Alliance 2790, 55 Waters) and an ESI source of time-of flight (TOF) mass spectrometer (Q-TOF, Waters). The system was controlled by Masslinx software (Waters). The separations were performed on a BDS Hypersil C18 (Thermo) analytical column (3 $\mu \mathrm{m}$ particle size, $2.1 \mathrm{~mm}, 50 \mathrm{~mm})$. In typical conditions, the elution was started with $60100 \%$ of mobile phase A (ACN with $10 \mathrm{mmol}$ of ammonium acetate) then solvent B (isopropanol) was increased from0 to $100 \%$ in $15 \mathrm{~min}$ with a $15-\mathrm{min}$ hold at $100 \% \mathrm{~B}$. The flow rate was set at $0.2 \mathrm{~mL} / \mathrm{min}$, and the injection volume was $50.0 \mu \mathrm{L}$. LC/ESI-MS chromatograms were recorded in the positive ion mode with the 65 capillary voltage set at $3000 \mathrm{~V}$ and cone voltage at $30 \mathrm{~V}$ while the dry temperature was set at $150^{\circ} \mathrm{C}$ and dry gas flow was maintained at $13 \mathrm{~L} / \mathrm{min}$. Size exclusion chromatography (SEC) was performed on a Spectra-Physics apparatus equipped with an RI Shodex refractive index detector. Two PL-gel mix C columns were used at $7070{ }^{\circ} \mathrm{C}$ with a $0.8 \mathrm{ml} / \mathrm{min}$ flow rate of DMF $(0.1 \% \mathrm{LiBr})$, calibrated using poly(methylmethacrylate) standards.Mass spectrometry analyses were conducted with a Bruker Ultra-Flex MALDI-Tof mass spectrometer, equipped with a nitrogen laser (LSI, $337 \mathrm{~nm}, 10$ ns pulse length) and one detector. Mixture of peptides was used for ${ }_{5}$ external calibration. The ions were accelerated by a potential of 25 $\mathrm{kV}$ and reflected with a $26.3 \mathrm{kV}$ potential. All measurements were recorded in the positive reflectron mode using $\alpha$-cyano-4hydroxycinnamic acid (HCCA) as matrix with NaI. For each spectrum 700 transients were accumulated. The resolution at $\mathrm{m} / \mathrm{z}=$ ${ }_{80} 1263.8$ was 6863.Dynamic light scattering (DLS) measurements were carried out at different scattering angles going from 20 to $155^{\circ}$ using an ALV/CGS-8F S/N 069 apparatus (ALV, Langen, Germany) equipped with a $35 \mathrm{~mW}$ red HeNe linearly polarized laser operating at a wavelength of $632.8 \mathrm{~nm}$ (JDSU, Milpitas, USA) and 85 an ALV/LSE-5004 multiple $\tau$ digital correlator with a $125 \mathrm{~ns}$ initial sampling time. The copolymer solutions were loaded in $10 \mathrm{~mm}$ diameter cylindrical cells and maintained at a constant temperature of $25.0^{\circ} \mathrm{C}$. The wave vector modulus (q) is equal to $(4 \pi \mathrm{n} / \lambda) \sin (\theta / 2)$ where $\mathrm{n}$ represents the refractive index of the pure solvent (water in 90 this case), $\lambda$ is the laser wavelength, and $\theta$ designates the scattering angle. Data were collected typically for $300 \mathrm{~s}$ using the ALV correlator control software. The relaxation time distribution was obtained using the CONTIN analysis of the autocorrelation functiong ${ }^{(2)}-1^{32}$.

\section{Characterization of rawlipids}

MethylOleate (MO). ${ }^{1} \mathrm{H}$ NMR $\left(300 \mathrm{MHz}, \mathrm{CDCl}_{3}\right), \delta=0.79-0.88(\mathrm{t}$, $\left.\mathrm{J}=7.0 \mathrm{~Hz}, 3 \mathrm{H}, \mathrm{CH}_{2}-\mathrm{CH}_{3}\right), 1.16-1.30\left(\mathrm{~m}, 19 \mathrm{H}, \mathrm{CH}_{2}\right), 1.6(\mathrm{t}, \mathrm{J}=7.0$ $\mathrm{Hz}, 2 \mathrm{H}, \mathrm{CH}_{2}-\mathrm{CH}_{2}-\mathrm{C}=\mathrm{O}$ ), 1.92-2.07( m, 3.5H, $\mathrm{CH}_{2}-\mathrm{CH}=\mathrm{CH}-$ ), 2.24- toluenesulfonyl chloride ( $\mathrm{TsCl}$ ) and chloroacetyl chloride (CAC) from Flukawere used without further purification. Dialysis 
$2.37\left(\mathrm{t}, \mathrm{J}=7.5 \mathrm{~Hz}, 2 \mathrm{H}, \mathrm{CH}_{2}-\mathrm{CH}_{2}-\mathrm{C}=\mathrm{O}\right), 2.74-2.78(\mathrm{t}, 0.26 \mathrm{H}$, negligible), 3.66 (s, 3H CH $\left.\mathbf{H}_{3}-\mathrm{O}-\mathrm{C}=\mathrm{O}\right), 5.21-5.42(\mathrm{~m}, 2 \mathrm{H}, \mathrm{CH}=\mathrm{CH})$.

${ }^{13} \mathrm{C}$ NMR (75.47 MHz, $\left.\mathrm{CDCl}_{3}\right), \delta=13.04\left(\mathrm{CH}_{2}-\mathrm{CH}_{3}\right), 22.66-31.8$ $\left(\mathbf{C H}_{2}\right), 34.9\left(\mathbf{C H}_{2}-\mathrm{C}=\mathrm{O}\right), 51.4\left(\mathbf{C H}_{3}-\mathrm{O}-\mathrm{C}=\mathrm{O}\right), 127.9$ (negligible), $5129.7(\mathbf{C H}=\mathbf{C H}), 174.3(\mathbf{C}=\mathrm{O})$.

FTIR $\left(\mathrm{cm}^{-1}\right)$ : 3003 (C=C-H (cis), asymmetrical elongation), 2929 (C-H, asymmetrical elongation), 2853 (C-H, symmetrical elongation $), \quad 1745 \quad\left(\mathrm{C}=\mathrm{O}_{\text {ester }}\right.$, elongation $), \quad 1459-1436 \quad\left(\mathrm{CH}_{2}\right.$ scissoring), $1355\left(\mathrm{CH}_{3}\right.$ symmetrical deformation $), 1167\left(\mathrm{C}-\mathrm{O}_{\text {ester }}\right.$ 10 elongation), $725\left(\mathrm{CH}_{2}\right.$ rocking).

GrapeSeed Oil (GSO). ${ }^{1} \mathrm{H}$ NMR $\left(300 \mathrm{MHz}, \mathrm{CDCl}_{3}\right), \delta=0.79-0.88$ $\left(\mathrm{m}, 9 \mathrm{H}, \mathrm{CH}_{2}-\mathrm{CH}_{3}\right), 1.16-1.30\left(\mathrm{~m}, 51.5 \mathrm{H}, \mathrm{CH}_{2}\right), 1.6\left(\mathrm{~m}, 6.5 \mathrm{H}, \mathrm{CH}_{2}-\right.$ $\mathrm{CH}_{2}-\mathrm{C}=\mathrm{O}$ ), 1.92-2.07 (m, $\left.10.8 \mathrm{H}, \mathrm{CH}_{2}-\mathrm{CH}=\mathrm{CH}-\right), 2.24-2.37$ (t, $\mathrm{J}=$ $\left.157.5 \mathrm{~Hz}, 6.1 \mathrm{H}, \mathrm{CH}_{2}-\mathrm{C}=\mathrm{O}\right), 2.74-2.78(\mathrm{t}, \mathrm{J}=5.9 \mathrm{~Hz}, 4 \mathrm{H},-\mathrm{CH}=\mathrm{CH}-$ $\left.\mathrm{CH}_{2}-\mathrm{CH}=\mathrm{CH}\right), 4.11-4.17\left(\mathrm{dd}, 2 \mathrm{H},{ }^{2} \mathrm{~J}=11.7 \mathrm{~Hz},{ }^{3} \mathrm{~J}=5.7 \mathrm{~Hz},{ }^{3} \mathrm{~J}=6\right.$ $\mathrm{Hz}, \mathrm{CH}_{2}-\mathrm{O}$ ), 4.26-4.32 (dd, $\left.2 \mathrm{H},{ }^{2} \mathrm{~J}=12 \mathrm{~Hz},{ }^{3} \mathrm{~J}=4.2 \mathrm{~Hz}, \mathrm{CH}_{2}-\mathrm{O}\right)$, 5.21-5.42 (m, $10.49 \mathrm{H}, \mathrm{CH}-\mathrm{O}$ and $\mathrm{CH}=\mathrm{CH})$.

${ }^{13} \mathrm{C}$ NMR (75.47 MHz, $\left.\mathrm{CDCl}_{3}\right), \delta=13.98\left(\mathrm{CH}_{2}-\mathrm{CH}_{3}\right), 22.49-31.8$ $20\left(\mathrm{CH}_{2}\right), 33.9-34.07\left(\mathrm{CH}_{2}-\mathrm{C}=\mathrm{O}\right), 61.9\left(\mathrm{CH}_{2}-\mathrm{O}\right), 68.8\left(\mathrm{CH}_{2}-\mathrm{CH}-\mathrm{O}\right)$, $127.8 \quad\left(\mathrm{CH}_{2}-\mathrm{CH}=\mathbf{C H}-\mathrm{CH}_{2}-\mathrm{CH}=\mathrm{CH}\right), \quad 130.05 \quad\left(\mathrm{CH}_{2}-\mathbf{C H}=\mathrm{CH}-\mathrm{CH}_{2}-\right.$ $\mathrm{CH}=\mathbf{C H}), 172.64-173.04(\mathbf{C}=\mathrm{O})$.

FTIR $\left(\mathrm{cm}^{-1}\right): 3003(\mathrm{C}=\mathrm{C}-\mathrm{H}(\mathrm{cis})$, asymmetrical elongation), 2920(C$\mathrm{H}$, asymmetrical elongation), $2850(\mathrm{C}-\mathrm{H}$, symmetrical elongation), $251742\left(\mathrm{C}=\mathrm{O}_{\text {ester }}\right.$, elongation $), 1459\left(\mathrm{CH}_{2}\right.$ scissoring $), 1377\left(\mathrm{CH}_{3}\right.$ symmetrical deformation), $1157\left(\mathrm{C}-\mathrm{O}_{\mathrm{ester}}\right.$ elongation $), 725\left(\mathrm{CH}_{2}\right.$ rocking).

GC: $65.9 \%$ C18 :2, $0.1 \%$ C16 :1, 2.7\% C18 :1, 0.5\% C18 :3, 6.9\% $\mathrm{C} 16: 0$ and $3.9 \% \mathrm{C} 18: 0$.

30

Modification of lipids

Synthesis of hydroxylated lipid.Similar procedure was followed for the modification of MO or GSO. MO or GSO, ME (3 eq with respect to $\mathrm{MO}$ or 3 eq per double bond of GSO triglyceride), and 0 , 350.02 or 0.1 eq of DMPA with respect to MO or GSO were dissolved in a minimal amount of THF required to obtain a homogeneous medium.

In both cases, reactions were performed in a Pyrex photoreactor where a UV lamp was inserted in a water temperature-controlled (at 40 about $20^{\circ} \mathrm{C}$ ) double jacket tube immersed in a larger tube containing raw materials. The UV lamp was an HPK $125 \mathrm{~W}$ high-pressure mercury vapor lamp of HeraeusNoblelight (maximum energy at a wavelength of $365 \mathrm{~nm}$, with substantial radiations at 435, 404, 313 and $253 \mathrm{~nm}$ ). After reaction, THF was removed and non-reacted ME 45 was extracted by washing the organic phase several times (EtOAc/brine). The organic phase was then dried over $\mathrm{MgSO}_{4}$ and solvent was evaporated by vacuum distillation. The resulting products were analyzed by NMR and IR spectroscopies.

${ }_{50}$ Hydroxylated Methyl Oleate (HMO). ${ }^{1} \mathrm{H}$ NMR $(300 \mathrm{MHz}$, $\left.\mathrm{CDCl}_{3}\right), \delta=0.79-0.88\left(\mathrm{t}, \mathrm{J}=7.0 \mathrm{~Hz}, 3 \mathrm{H}, \mathrm{CH}_{2}-\mathrm{CH}_{3}\right), 1.16-1.7(\mathrm{~m}$, 27H, $\mathbf{C H}_{2}$ ), 2.24-2.37 (t, J = 7.5 Hz, $\left.2 \mathrm{H},-\mathrm{CH}_{2}-(\mathrm{C}=\mathrm{O})-\right), 2.56$ (q, $1 \mathrm{H}, \mathrm{J}=12.4,6.3 \mathrm{~Hz}, \mathrm{CH}-\mathrm{S}), 2.71\left(\mathrm{t}, 2 \mathrm{H}, \mathrm{J}=6.0 \mathrm{~Hz}, \mathrm{~S}-\mathrm{CH}_{2}\right), 3.66$ (s, 3H, $\mathrm{CH}_{3}-\mathrm{O}-(\mathrm{C}=\mathrm{O})-$ ) , 3.66-3.76 (t, 2H, $\left.\mathrm{CH}_{2}-\mathrm{OH}\right)$.

${ }_{55}{ }^{13} \mathrm{C}$ NMR (75.47 MHz, $\left.\mathrm{CDCl}_{3}\right), \delta=14.2\left(\mathrm{CH}_{2}-\mathrm{CH}_{3}\right), 22.7-31.9$ $\left(\mathbf{C H}_{2}, \mathrm{~S}-\mathrm{CH}_{2}-\mathrm{CH}_{2}-\mathrm{OH}\right), 34.1\left(\mathbf{C H}_{2}-(\mathrm{C}=\mathrm{O})-\right), 35.0\left(\mathbf{C H}_{2}-\mathrm{CH}-\mathrm{S}\right), 45.1$ $\left(\mathbf{C H}-\mathrm{S}-\mathrm{CH}_{2}\right), 51.6\left(\mathrm{CH}_{3}-\mathrm{O}-(\mathrm{C}=\mathrm{O})-\right), 60.9\left(\mathrm{CH}_{2}-\mathrm{OH}\right), 127.9-129.7$ (negligible, residual double bonds), $174.4(\mathbf{C}=\mathrm{O})$.

FTIR $\left(\mathrm{cm}^{-1}\right): 3440(\mathrm{OH}$, stretching), $2923(\mathrm{C}-\mathrm{H}$, asymmetrical 60 elongation), $2854\left(\mathrm{C}-\mathrm{H}\right.$, symmetrical elongation), $1739\left(\mathrm{C}=\mathrm{O}_{\text {ester }}\right.$, elongation), 1456-1433 ( $\mathrm{CH}_{2}$ scissoring), $1362\left(\mathrm{CH}_{3}\right.$ symmetrical

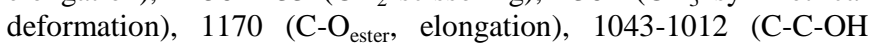
mercaptoethanol), $725\left(\mathrm{CH}_{2}\right.$ rocking).

${ }_{65}$ HydroxylatedGrapeSeed Oil (HGSO). ${ }^{1} \mathrm{H}$ NMR $(300 \mathrm{MHz}$, $\left.\mathrm{CDCl}_{3}\right), \delta=0.79-0.88\left(9 \mathrm{H}, \mathrm{CH}_{2}-\mathrm{CH}_{3}\right), 1.16-1.50\left(49 \mathrm{H}, \mathrm{CH}_{2}\right), 1.5-$ $1.7\left(9.5 \mathrm{H}, \mathrm{CH}_{2}-\mathrm{CH}-\mathrm{S}\right.$ and $\left.\mathrm{CH}_{2}-\mathrm{CH}_{2}-(\mathrm{C}=\mathrm{O})-\right), 1.92-2.07(8.35 \mathrm{H}$,
$\left.\mathrm{CH}_{2}-\mathrm{CH}=\mathrm{CH}-\right), 2.24-2.37$ (t, 7H, $\left.{ }^{3} \mathrm{~J}=7.5 \mathrm{~Hz}, \mathrm{CH}_{2}-(\mathrm{C}=\mathrm{O})-\right), 2.5-2.8$ $\left(\mathrm{m}, \mathrm{CH}=\mathrm{CH}-\mathrm{CH}_{2}-\mathrm{CH}=\mathrm{CH}, \mathrm{CH}-\mathrm{S}\right.$ and $\left.\mathrm{S}-\mathrm{CH}_{2}\right), 3.6-3.8\left(\mathrm{dd}, \mathrm{CH}_{2-}\right.$ $\left.{ }_{0} \mathrm{OH}\right), 4.11-4.17\left(\mathrm{dd}, 2 \mathrm{H},{ }^{2} \mathrm{~J}=11.7 \mathrm{~Hz},{ }^{3} \mathrm{~J}=5.7 \mathrm{~Hz},{ }^{3} \mathrm{~J}=6 \mathrm{~Hz}, \mathrm{CH}_{2}-\right.$ O), 4.26-4.32 (dd, $\left.2 \mathrm{H},{ }^{2} \mathrm{~J}=12 \mathrm{~Hz},{ }^{3} \mathrm{~J}=4.2 \mathrm{~Hz}, \mathrm{CH}_{2}-\mathrm{O}\right), 5.21-5.42$ $(\mathrm{m}, 7.57 \mathrm{H}, \mathrm{CH}-\mathrm{O}$ and $\mathrm{CH}=\mathrm{CH}$ ).

${ }^{13} \mathrm{C}$ NMR (75.47 MHz, $\left.\mathrm{CDCl}_{3}\right), \delta=14.1\left(\mathrm{CH}_{2}-\mathrm{CH}_{3}\right), 22.49-35$ $\left(\mathbf{C H}_{2}\right), 45.1\left(\mathbf{C H}-\mathrm{S}-\mathrm{CH}_{2}\right), 61.9\left(\mathbf{C H}_{2}-\mathrm{O}\right.$ and $\left.\mathbf{C H}_{2}-\mathrm{OH}\right), 68.8\left(\mathrm{CH}_{2}-\right.$ $\mathbf{C H}-\mathrm{O}), \quad 127.8-130.05\left(\mathrm{CH}_{2}-\mathrm{CH}=\mathbf{C H}-\mathrm{CH}_{2}-\mathrm{CH}=\mathrm{CH}\right), \quad 172.9-173.3$ $(\mathbf{C}=\mathrm{O})$.

FTIR $\quad\left(\mathrm{cm}^{-1}\right): 3457 \quad(\mathrm{OH}, \quad$ stretching $), 3009 \quad(\mathrm{C}=\mathrm{C}-\mathrm{H} \quad$ (cis), asymmetrical elongation), 2923 (C-H, asymmetrical elongation), 2850 (C-H, symmetrical elongation), 1738 ( $\mathrm{C}=\mathrm{O}_{\text {ester }}$, elongation), so $1462\left(\mathrm{CH}_{2}\right.$ scissoring), $1374\left(\mathrm{CH}_{3}\right.$ symmetrical deformation), 1167 (C-O $\mathrm{C}_{\text {ester }}$ elongation), 1043-964 (C-C-OH $\left.\mathrm{OH}_{\text {mercaptoethanol }}\right), 725\left(\mathrm{CH}_{2}\right.$ rocking)

Synthesis of initiators for cationic ring-opening 5 polymerization. The reaction between hydroxylated lipids and $p$ toluenesulfonyle chloride $(\mathrm{TsCl})$ was achieved as previously reported $^{33}$. Hydroxylated lipids were dissolved in distilled chloroform $(0.5 \mathrm{M})$ stored under dried nitrogen atmosphere. 2 eq of triethylamine was introduced and the mixture was left under dry nitrogen stream for half an hour and cooled down in an ice bath. $\mathrm{TsCl}$ dissolved in distilled chloroform $(0.5 \mathrm{M})$ was added dropwise at $0^{\circ} \mathrm{C}$ and left at room temperature during $24 \mathrm{hrs}$. The resulting product was purified by washing the organic part with brine (EtOAc/brine) several times, analyzed by NMR and LC-MS.

95 The reaction between hydroxylated lipids and trifluoromethanesulfonic anhydride ${ }^{27,29,34}$ was performed in a double jacket reactor. Anhydrous potassium carbonate (10 eq) and hydroxylated lipid (1eq, $1 \mathrm{M}$ ) were dissolved in distilled chloroform and stirred under dry nitrogen before cooling at $-20^{\circ} \mathrm{C}$. Then a solution of trifluoromethanesulfonic anhydride (2 eq) in distilled chloroform (4 M) was added dropwise. The mixture was stirred at $20^{\circ} \mathrm{C}$ for $2 \mathrm{hrs}$ then $2 \mathrm{hrs}$ at $0^{\circ} \mathrm{C}$, and finally, let at RT till the end of reaction $(20 \mathrm{hrs})$. The mixture was filtered, the solvent and the residues were removed under vacuum.

The reaction between hydroxylated lipids and chloroacetylchloride was achieved in a tricol equipped with a condenser. Hydroxylated lipid (1eq), triethylamine (1.1 eq) and anhydrous dichloromethane were mixed and cooled down in an ice bath and left under dry nitrogen stream. A solution of chloroacetyl chloride (1.5 eq) in dichloromethane was added dropwise. Reaction was completed after stirring at $0^{\circ} \mathrm{C}$ during $30 \mathrm{~min}$ and the product was purified by washing the organic part with brine (EtOAc/brine) several times.

Chloro-Methyl Oleate (Cl-MO). ${ }^{1} \mathrm{H}$ NMR $\left(300 \mathrm{MHz}, \mathrm{CDCl}_{3}\right), \delta=$ 15 0.79-0.88 (t, J = 7.0 Hz, 3H, CH $\left.\mathrm{CH}_{2}-\mathrm{CH}_{3}\right), 1.16-1.7\left(\mathrm{~m}, 27 \mathrm{H}, \mathrm{CH}_{2}\right)$, 2.24-2.33 (t, J = 7.5 Hz, $\left.2 \mathrm{H},-\mathrm{CH}_{2}-(\mathrm{C}=\mathrm{O})-\right), 2.6$ (q, 1H, J = 12.4, 6.3 $\mathrm{Hz}, \mathrm{CH}-\mathrm{S}$ ), 2.73 (t, J = 7.2 Hz, 2H, S-CH $), 3.65$ (s, 3H, CH $\mathbf{H}_{3}-\mathrm{O}-$ $(\mathrm{C}=\mathrm{O})-), 4.06$ (s, 2H, CH $2-\mathrm{Cl}$ ), 4.27-4.34 (t, J = 7.1 Hz, 2H, $\mathrm{CH}_{2}-\mathrm{O}-$ $\left.(\mathrm{C}=\mathrm{O})-\mathrm{CH}_{2}-\mathrm{Cl}\right)$.

${ }^{13} \mathrm{C} \mathrm{NMR}\left(75.47 \mathrm{MHz}, \mathrm{CDCl}_{3}\right), \delta=14.2\left(\mathrm{CH}_{2}-\mathrm{CH}_{3}\right), 22.7-31.9$ $\left(\mathbf{C H}_{2}\right), 34.2\left(\mathbf{C H}_{2}-(\mathrm{C}=\mathrm{O})-\right), 35.0\left(\mathbf{C H}_{2}-\mathrm{CH}-\mathrm{S}\right), 40.9\left(\mathbf{C H}_{2}-\mathrm{Cl}\right), 46.6$ $\left(\mathbf{C H}-\mathrm{S}-\mathrm{CH}_{2}\right), 51.5\left(\mathbf{C H}_{3}-\mathrm{O}-(\mathrm{C}=\mathrm{O})-\right), 65.6\left(\mathbf{C H}_{2}-\mathrm{O}-(\mathrm{C}=\mathrm{O})-\mathrm{CH}_{2}-\mathrm{Cl}\right)$, 127.9-129.7 (negligible residual double bonds), 167.2 (O- $(\mathbf{C}=\mathrm{O})$ $\left.\mathrm{CH}_{2}-\mathrm{Cl}, \mathrm{C}-23\right), 174.4(\mathbf{C}=\mathrm{O})$.

${ }_{25}$ FTIR $\left(\mathrm{cm}^{-1}\right)$ : 2920 (C-H, asymmetrical elongation), 2850 (C-H, symmetrical elongation), $1736\left(\mathrm{C}=\mathrm{O}_{\text {ester }}\right.$, elongation $), 1459-1432$ $\left(\mathrm{CH}_{2}\right.$, scissoring), $1377\left(\mathrm{CH}_{3}\right.$, symmetrical deformation), 1159 (C$\mathrm{O}_{\text {ester, }}$, elongation), $776\left(\mathrm{C}-\mathrm{Cl}\right.$, stretching), $725\left(\mathrm{CH}_{2}\right.$, rocking).

${ }_{130}$ Chloro-GrapeSeed Oil (Cl-GSO). ${ }^{1} \mathrm{H}$ NMR (300 MHz, $\left.\mathrm{CDCl}_{3}\right), \delta=$ 0.79-0.88 (9H, $\left.\mathrm{CH}_{2}-\mathrm{CH}_{3}\right), 1.16-1.70\left(63 \mathrm{H}, \mathrm{CH}_{2}, \mathrm{CH}_{2}-\mathrm{CH}-\mathrm{S}\right.$ and $\left.\mathrm{CH}_{2}-\mathrm{CH}_{2}-(\mathrm{C}=\mathrm{O})-\right), 1.92-2.07\left(9 \mathrm{H}, \mathrm{CH}_{2}-\mathrm{CH}=\mathrm{CH}-\right), 2.24-2.37(\mathrm{t}, 7 \mathrm{H}$, $\left.{ }^{3} \mathrm{~J}=7.5 \mathrm{~Hz}, \mathrm{CH}_{2}-(\mathrm{C}=\mathrm{O})-, \mathrm{H}-4\right), 2.5-2.8\left(\mathrm{~m}, 5 \mathrm{H}, \mathrm{CH}=\mathrm{CH}-\mathrm{CH}_{2}-\right.$ 
$\mathrm{CH}=\mathrm{CH}, \mathrm{CH}-\mathrm{S}$ and $\left.\mathrm{S}-\mathrm{CH}_{2}\right), 4.11-4.32\left(\mathrm{~m}, 8 \mathrm{H}, \mathrm{CH}_{2}-\mathrm{O}, \mathrm{CH}_{2}-\mathrm{O}-\right.$ $\left.(\mathrm{C}=\mathrm{O})-\mathrm{CH}_{2}-\mathrm{Cl}, \mathrm{CH}_{2}-\mathrm{Cl}\right), 5.21-5.42(\mathrm{~m}, 7.7 \mathrm{H}, \mathrm{CH}-\mathrm{O}$ and $\mathrm{CH}=\mathrm{CH})$.

${ }^{13} \mathrm{C}$ NMR (75.47 MHz, $\left.\mathrm{CDCl}_{3}\right), \delta=14.1\left(\mathrm{CH}_{2}-\mathrm{CH}_{3}\right), 22.49-35.7$ $\left(\mathrm{CH}_{2}\right.$ and $\left.\mathrm{S}-\mathrm{CH}_{2}\right), 40.8\left(\mathrm{CH}_{2}-\mathrm{Cl}\right), 46.3(\mathbf{C H}-\mathrm{S}), 62.1\left(\mathrm{CH}_{2}-\mathrm{O}\right), 65.3$ ${ }_{5}\left(\mathrm{CH}_{2}-\mathrm{O}-(\mathrm{C}=\mathrm{O})-\mathrm{CH}_{2}-\mathrm{Cl}\right), \quad 69.1 \quad(\mathbf{C H}-\mathrm{O}), \quad 127.8-130.05 \quad\left(\mathrm{CH}_{2}-\right.$ $\left.\mathrm{CH}=\mathbf{C H}-\mathrm{CH}_{2}-\mathbf{C H}=\mathrm{CH}\right), \quad 167.2 \quad\left(-(\mathbf{C}=\mathrm{O})-\mathrm{CH}_{2}-\mathrm{Cl}\right), \quad 172.9-173.3$ $(\mathbf{C}=\mathrm{O})$.

FTIR ( $\left.\mathrm{cm}^{-1}\right): 3009$ (C=C-H (cis), asymmetrical elongation), 2920 (C-H, asymmetrical elongation), 2850 (C-H, symmetrical 10 elongation), $1742\left(\mathrm{C}=\mathrm{O}_{\text {ester }}\right.$, elongation $), 1459\left(\mathrm{CH}_{2}\right.$ scissoring $)$, $1377\left(\mathrm{CH}_{3}\right.$, symmetrical deformation $), 1159\left(\mathrm{C}-\mathrm{O}_{\text {ester }}\right.$, elongation $)$, 772 (C-Cl, stretching), $725\left(\mathrm{CH}_{2}\right.$, rocking).

CROP of MOx using halogeno-lipid macroinitiators. All reactions 15 were carried out under dry nitrogen atmosphere. NaI (1 eq) in dry acetonitrile was added dropwise to a $0.5 \mathrm{M}$ solution of chloro-lipids in dry acetonitrile. The mixture was vigorously stirred $5 \mathrm{~min}$ at $78^{\circ} \mathrm{C}$ and MOx was added. The concentration of monomer in the final mixture was $4 \mathrm{M}$ since transfer reactions can be avoided in the range 20 from 4 to $7 \mathrm{M}^{35}$. The solution was stirred at $78^{\circ} \mathrm{C}$ during $24 \mathrm{hrs}$ and samples were withdrawn at different times of polymerization. Each aliquot was quenched by addition of an adequate amount of piperidine ( 5 eq). After cooling, the polymer was isolated by 3 successive precipitations from cold diethyl ether (where the non-

25 functionalized GSO, residual $\mathrm{MOx}$ and piperidine remained soluble). Dialysis of the final product was performed in water during 3 days. The desired chain length was reached by varying the ratio $[\mathrm{M}] /[\mathrm{I}]([\mathrm{MOx}] /[$ macroinitiator $])$ or the polymerization duration.

${ }_{30}$ Polymers based on MO (MO-POx). ${ }^{1} \mathrm{H}$ NMR (300 MHz, $\left.\mathrm{CDCl}_{3}\right), \delta$ $=0.79-0.88$ (t, $\mathrm{CH}_{2}-\mathrm{CH}_{3}$ lipid ), 1.16-1.65 (m, $\mathrm{CH}_{2}$ lipid), 1.67 ( $\mathrm{CH}_{2}-$ $\mathrm{CH}_{2}-\mathrm{CH}_{2}-\mathrm{N}$ piperidine), $1.88\left(\mathrm{CH}_{2}-\mathrm{CH}_{2}-\mathrm{N}\right.$ piperidine $), 1.9-2.2$ $\left(\mathrm{CH}_{3}-(\mathrm{C}=\mathrm{O})-\mathrm{N}\right.$ POx), 2.27-2.31 (t, $2 \mathrm{H}, \mathrm{CH}_{2}-(\mathrm{C}=\mathrm{O})-$ lipid $), 2.6(\mathrm{~m}$, CH-S lipid), 2.73 (m, S-CH lipid), 3.1-3.15 ( $\mathrm{t}, \mathrm{CH}_{2}-\mathrm{N}$ piperidine), ${ }_{35}$ 3.3-3.6 (m, $\left.\mathrm{CH}_{2}-\mathrm{C} \mathbf{H}_{2}-\mathrm{N}-(\mathrm{C}=\mathrm{O})-\mathrm{POx}\right), 3.65$ (s, $\mathrm{CH}_{3}-\mathrm{O}-(\mathrm{C}=\mathrm{O})-$ lipid), 4.1 (m, - $(\mathrm{C}=\mathrm{O})-\mathrm{CH}_{2}-\mathrm{N}-(\mathrm{C}=\mathrm{O})-$ lipid $), 4.1-4.3\left(\mathrm{~m}, \mathrm{~S}_{-} \mathrm{CH}_{2}-\right.$ $\mathrm{CH}_{2}-\mathrm{O}$ lipid).

${ }^{13} \mathrm{C}$ NMR (75.47 MHz, $\left.\mathrm{CDCl}_{3}\right), \delta=14.2\left(\mathrm{CH}_{2}-\mathrm{CH}_{3}\right.$ lipid), 22.7-31.9 $\left(\mathbf{C H}_{2}\right.$ lipid and piperidine), $34.1\left(\mathbf{C H}_{2}-(\mathrm{C}=\mathrm{O})-\right.$ lipid), $34.9\left(\mathbf{C H}_{2}-\mathrm{CH}-\right.$ ${ }_{40} \mathrm{~S}$ lipid), 43-50 (CH-S lipid, $\mathbf{C H}_{2}-\mathbf{C H}_{2}-\mathrm{N}-\mathrm{C}=\mathrm{O}$ POx, $\mathbf{C H}_{2}-\mathrm{N}$ piperidine $), 49.6\left(-(\mathrm{C}=\mathrm{O})-\mathrm{CH}_{2}-\mathrm{N}-(\mathrm{C}=\mathrm{O})-\right.$ lipid $), 51.5 \quad\left(\mathrm{CH}_{3}-\mathrm{O}-\right.$ $(\mathrm{C}=\mathrm{O})-$ lipid), $64.0 \quad\left(\mathrm{~S}-\mathrm{CH}_{2}-\mathrm{CH}_{2}\right.$ lipid $), 169.2 \quad\left(-(\mathbf{C}=\mathrm{O})-\mathrm{CH}_{2}-\mathrm{N}-\right.$ lipid), 170.9-171.6 (N-(C=O)- $\left.\mathrm{CH}_{3} \mathrm{POx}\right), 174.4\left(\mathrm{CH}_{3}-(\mathbf{C}=\mathrm{O})-\right.$ lipid $)$.

${ }_{45}$ Polymer based on GSO (GSO-POx). ${ }^{1} \mathrm{H}$ NMR (300 MHz, $\mathrm{CDCl}_{3}$ ), $\delta=0.79-0.88$ ( $\mathrm{t}, \mathrm{CH}_{2}-\mathrm{CH}_{3}$ lipid), 1.16-1.65 (m, $\mathrm{CH}_{2}$, lipid), 1.67 $\left(\mathrm{CH}_{2}-\mathrm{CH}_{2}-\mathrm{CH}_{2}-\mathrm{N}\right.$, piperidine $), 1.88-2.2\left(\mathrm{CH}_{2}-\mathrm{CH}=\mathrm{CH}\right.$ lipid, $\mathrm{CH}_{3}-$ $(\mathrm{C}=\mathrm{O})-\mathrm{N}$ POx, $\mathrm{CH}_{2}-\mathrm{CH}_{2}-\mathrm{N}$, piperidine), 2.27-2.31 (t, $\mathrm{CH}_{2}-(\mathrm{C}=\mathrm{O})-$ lipid), 2.6 (m, CH-S lipid), 2.73 (m, S-CH lipid), 2.77 ( $\mathrm{CH}=\mathrm{CH}-$ ${ }_{50} \mathrm{CH}_{2}-\mathrm{CH}=\mathrm{CH}$ lipid), 3.1-3.15 (t, $\mathrm{CH}_{2}-\mathrm{N}$ piperidine), 3.3-3.6 (m, $\left.\mathrm{CH}_{2}-\mathrm{CH}_{2}-\mathrm{N}-(\mathrm{C}=\mathrm{O})-\mathrm{POx}\right), 4.1\left(\mathrm{~m},-(\mathrm{C}=\mathrm{O})-\mathrm{CH}_{2}-\mathrm{N}-(\mathrm{C}=\mathrm{O})-\right.$ lipid $)$, 4.1-4.3 (m, S-CH $-\mathrm{CH}_{2}$ lipid), 4.11-4.32 (dd, $\mathrm{CH}_{2}-\mathrm{O}$ glycerol), 5.25 (CH-O, glycerol), 5.3-5.42 (m, $\mathrm{CH}=\mathrm{CH}$, lipid).

\section{Results and discussion}

${ }_{55}$ Grapeseed oil and its fatty esters were firstly converted into lipidic alcohols thanks to the addition of 2-mercaptoethanol (ME) onto double bonds using thiol-ene coupling (TEC) reaction. The resulting modified lipids were further transformed into macroinitiators for the polymerization of MOx. Then, the self-organization in aqueous 60 solution of the obtained amphiphilicmoleculeswas investigated.

\section{Functionalization of vegetable oils and derivatives by thiol-ene coupling}

The low reactivity of natural lipids requires a preliminary chemical modification of the backbone in order to enhance their reactivity. A 65 wide range of chemical modifications has been explored so far. The most usual methodologies involved the modification of the double bonds into epoxy functions (epoxydation ${ }^{36}$ ), (meth)acrylate functions (acrylation of alcohol ${ }^{37}$ or epoxy groups ${ }^{38}$ ), acid functions $\left(\right.$ oxidation $^{39}$ ), succinic anhydride group (maleinisation ${ }^{40}$ ) and others. 70 The introduction of alcohol groups can be achieved by hydroxylation $^{41}$, ozonolysis and reduction ${ }^{42}$, phenolation ${ }^{43}$, hydroformylation $^{44}$ and thiol-ene addition of hydroxylated mercaptan ${ }^{45}$. This latter route named thiol-ene coupling (TEC) is the well-known addition of mercaptans onto unsaturations ${ }^{46}$. The

75 mechanism of this reaction can be either a nucleophilic type reaction when the base-catalyzed thio-Michael reaction is involved, or a radical one ${ }^{47}$. Radicals can be produced by heating or exposure to UV radiation with or without any initiator. The mechanism of addition has been extensively studied ${ }^{48,49}$ and the influence of both 80 structures of the thiols ${ }^{50}$ and unsaturated alkyl chains ${ }^{51}$ were investigated. The effect of the initiator type $\mathrm{p}^{52}$ was reported as well as the influence of the wavelength ${ }^{53}$ and the intensity ${ }^{54}$ of the light in the case of photochemical activation. This type of chemistry has been widely used on vegetable oils and their derivatives ${ }^{45,55}$. Various 85 parameters were studied such as reaction mechanism, kinetics ${ }^{55 \mathrm{~d}}$, configuration of the unsaturations and isomerization phenomena ${ }^{55 b, c, 56}$, influence of conjugated and non-conjugated structure of lipids ${ }^{55 \mathrm{j}}$, impact of the number of double bonds of the alkyl chain $^{55 \mathrm{i}}$ and side reactions ${ }^{45}$. The TEC reaction exhibits many 90 advantages in functionalizing lipids. For instance, in the case of hydroxylated lipids, the alkyl chains can be modified with primary hydroxyl functions which are more reactive than secondary ones, generally obtained by ring-opening of epoxidized oils ${ }^{57}$. Experiments can be performed under air since oxygen does not 5 inhibit the reaction as is reported by several authors $58,47,59$

In recent work on the TEC reaction ${ }^{45,60}$, we showed that the thermal method may promote oxidation and oligomerization of vegetable oils ${ }^{55 \mathrm{k}}$. In the present study, photochemical induced TEC was chosen instead of the thermal route to reduce side reactions occurring on lipids.

The thiol-ene reaction can be initiated at both 254 and $365 \mathrm{~nm}$ as previously reported ${ }^{53}$. However, wavelength of $254 \mathrm{~nm}$ induces a direct cleavage of thiol groups in $\mathrm{RS}^{\circ}$ and $\mathrm{H}^{\circ}$, and in the presence of olefin, the $\mathrm{H}^{\circ}$ radical is very quickly added onto double bonds of 5 lipidic chains leading to a carbo-centered radical. This latter reacts with another thiol ${ }^{55 \mathrm{c}}$ by abstracting one proton. Consequently, andaccording to this mechanism, hydrogenated alkyl chains are produced as side products. Even if the mechanism operating at $365 \mathrm{~nm}$ is not well understood, this wavelength seems to be more 10 appropriate for TEC and has been largely used. Under those conditions, the addition of thiol moiety onto double bonds is favored. Moreover, it has been highlighted that type I photoinitiators such as DMPA lead to the highest efficiencies at this wavelength ${ }^{52}$. For our systems, the TEC reaction was performed onto MO and 115 AGSO at $365 \mathrm{~nm}$ with and without DMPA. MO was chosen as a model of vegetable oil because it is the simpler and the close species of vegetable oil exhibiting one double bond on the alkyl chain. This modeling aimed to validate each step of the general strategy to modify MO before applying it in a second part to crude oil.

20 First, the TEC reaction with MO was performed according to a protocol previously developed in our laboratory ${ }^{45}$ (step 1 , Scheme 1). An excess of thiol (3 eq of thiol per double bond) and 0.1 eq of DMPA are required for a total consumption of unsaturations and a short reaction time. The TEC reaction was monitored by ${ }^{1} \mathrm{H}$ NMR 25 spectroscopy observing the disappearance of double bond peaks between 5.21 and $5.42 \mathrm{ppm}$. The yield reached a maximum after 4hrs under UV exposure and all the double bonds were consumed as illustrated in Figure 1a. The addition of ME was confirmed by the quasi-total disappearance of double bond peaks (at 5.21-5.42 ppm) 
and the appearance of news peaks at $2.56 \mathrm{ppm} \mathrm{CH-S,} 2.71 \mathrm{ppm} \mathrm{S-} 55$ $\mathrm{CH}_{2}$ and 3.66-3.7 ppm $\mathrm{CH}_{2}-\mathrm{OH}(\mathrm{H}-2, \mathrm{H}-3$ and $\mathrm{H}-4$, respectively). ${ }^{13} \mathrm{C}$ NMR analysis confirmed this result with the quasidisappearance of double bonds at 127.8-130.05 ppm $(\mathbf{C H}=\mathbf{C H})$ and 5 the appearance of peaks at $45.1\left(\mathbf{C H}-\mathrm{S}-\mathrm{CH}_{2}\right)$ and $60.9 \mathrm{ppm}\left(\mathrm{CH}_{2^{-}}\right.$ $\mathrm{OH})$. FTIR analysis showed the appearance of a large peak at 3430 $\mathrm{cm}^{-1}$ corresponding to the alcohol function of the added mercaptoethanol, peaks at $1045-1012 \mathrm{~cm}^{-1}$ characteristic of C-C-OH of ME and the disappearance of double bonds at $3003 \mathrm{~cm}^{-1}$. This 10 functionalized fatty ester, called hydroxylated methyloleate (HMO), was obtained with good yield $\left(\rho_{\mathrm{m}}=94 \%\right)$. Furthermore, the FTIR spectra did not reveal any peak at $2560 \mathrm{~cm}^{-1}$ (S-H vibration) confirming the total elimination of residual ME and the efficiency of the purification step.

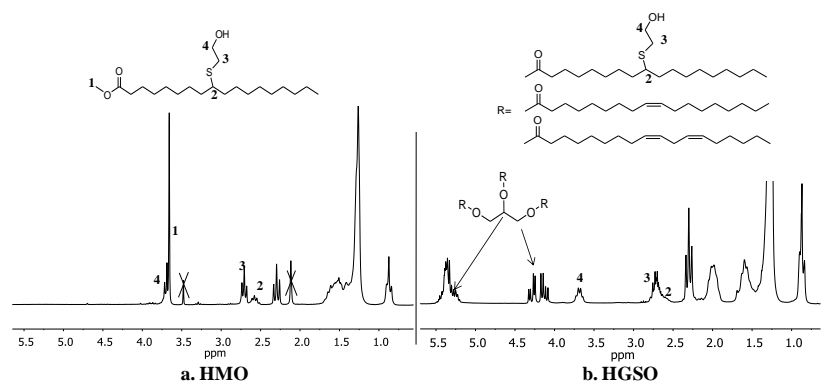

Fig $1^{1} \mathrm{H}$ NMR spectra of hydroxylated lipids: a. HMO and $b$. HGSO.

These experimental conditions were applied to grapeseed oil (GSO). 20 As described in the experimental part, GSO exhibits around 4.75 double bonds per triglyceride. One of the objectives of our investigation was to obtain a triglyceride bearing only one hydroxyl group per molecule. Followingour conditions, an excess of 3 eq of thiol reagent per double bond was reacted and the initial mixture 25 was diluted with a minimum of solvent (THF) since starting reagents were immiscible. As in the case of methyloleate, similar new peaks were observed in ${ }^{1} \mathrm{H}$ NMR, ${ }^{13} \mathrm{C}$ NMR and FTIR spectra. The influence of the use of photoinitiator and the UV time exposure was now investigatedand the results are listed inTable 1 . The 30 conversion rate was expressed by the decrease of double bonds using ${ }^{1} \mathrm{H}$ NMR data according to equation 1 :

$\%$ of consumed $\mathrm{C}=\mathrm{C}=\frac{\int 5.2 \mathrm{ppm}-5.5 \mathrm{ppm}(\mathrm{t})-1}{\int 5.2 \mathrm{ppm}-5.5 \mathrm{ppm}(\mathrm{t}=0)-1}$

35 The use of DMPA as the photoinitiator increased drastically the conversion rate (Entries 1 and 3) 11\% instead of $50 \%$ without DMPA after $4 \mathrm{hrs}$ of UV exposure. Increasing the time to $8 \mathrm{hrs}$ led to $63 \%$ of consumption of double bonds (Entry 2). One has to keep in mind that our goal was to insert only one hydroxyl function per 40 triglyceride. As the photoinitiator enhanced drastically the reactivity, we decided to perform the reaction without DMPA where the conversion rate of the reaction depended only on the duration of UV exposure ${ }^{45}$. Furthermore, we mention that the total elimination of residual DMPA according to usual purification procedure was 45 difficult to achieve and that residual quantities of DMPA could generate early ageing of the final product. In our conditions, we observed that the conversion rate ranged from $11 \%$ (4 hrs of reaction) to $39 \%$ (48 hrs) (Entries 3 to 6). The theoretical conversion rate fitting with the desired mono-adduct compound is $27 \%$ (Entry

505 ). In order to be more accurate in the calculation, one notesthat $27 \%$ of consumption of double bonds corresponds to $22 \%$ of added thiols. The percentage of added thiol was determined by ${ }^{1} \mathrm{H}$ NMR (equation 2):

$$
\% \text { thiol }_{\text {added }}=\frac{\int 2.7 \mathrm{ppm}}{2}
$$

The low gap between the two percentages was attributed to side reactions aspreviously reported ${ }^{45}$.

Table 1Results of UV initiated TEC between ME and GSO using 60 DMPA as photoinitiator.

\begin{tabular}{c|c|c|c} 
Entry & Eq DMPA* & $\begin{array}{c}\text { Irradiation } \\
\text { duration (hrs) }\end{array}$ & $\begin{array}{c}\% \text { of consumed } \\
\mathrm{C}=\mathrm{C}\end{array}$ \\
\hline 1 & 0.02 & 4 & 50 \\
2 & 0.02 & 8 & 63 \\
3 & - & 4 & 11 \\
4 & - & 8 & 24 \\
5 & - & 24 & 27 \\
6 & - & 48 & 39 \\
* Molar equivalent quantity of DMPA with respect to double bonds.
\end{tabular}

In our conditions, the analyses showed that TEC reaction did not lead to any degradation of the triglyceride as observed on ${ }^{1} \mathrm{H}$ NMR spectra (Figure 1b) where the characteristic peaks of the glycerol esters between 4.2 and $4.4 \mathrm{ppm}$ for $\mathrm{CH}_{2}-\mathrm{O}-\mathrm{C}=\mathrm{O}$ and at $5.2 \mathrm{ppm}$ for ${ }_{65} \mathrm{CH}-\mathrm{O}-\mathrm{C}=\mathrm{O}$ remained unchanged. Hydroxylated grape seed oil (HGSO) was obtained in good yield $(92 \%)$. Moreover, the presence of some di-hydroxylated triglycerides was observed in LC-MS and the various detected compounds are summarized in Table 2. Each species exhibited secondary alcohol appearing during the TEC 70 reaction (mentioned $\mathrm{OH}$ in $\mathrm{m} / \mathrm{z}$ data of Table 2).

Table 2LC-MS data of HGSO (sample with $22 \%$ of addition).

\begin{tabular}{c|c|c}
\multicolumn{2}{c|}{ Detected compounds } & \multirow{2}{*}{$\mathrm{m} / \mathrm{z}$} \\
\cline { 1 - 2 } $\mathrm{C}=\mathrm{C}$ & ME grafted & $\begin{array}{c}1056.9(\mathrm{M})^{+} \text {and } 1078.9(\mathrm{M})^{\mathrm{Na}+} \\
\text { TAG bearing } 2 \mathrm{C}=\mathrm{C}+\mathrm{OH}+2 \text { grafted ME }\end{array}$ \\
\hline 2 & 2 & $\begin{array}{c}1058.9(\mathrm{M})^{+} \text {and } 1080.9(\mathrm{M})^{\mathrm{Na}+} \\
\text { TAG bearing } 1 \mathrm{C}=\mathrm{C}+\mathrm{OH}+2 \text { grafted ME }\end{array}$ \\
\hline 1 & 2 & $1060.9(\mathrm{M})^{+}(\mathrm{TAG}+\mathrm{OH}+2$ grafted ME) \\
\hline 3 & 2 & $\begin{array}{c}978.8(\mathrm{M})^{+} \\
\text {TAG bearing } 3 \mathrm{C}=\mathrm{C}+\mathrm{OH}+\text { grafted ME }\end{array}$ \\
\hline 2 & 1 & $\begin{array}{r}980.8(\mathrm{M})^{+} \\
\text {TAG bearing } 2 \mathrm{C}=\mathrm{C})+\mathrm{OH}+\text { grafted ME }\end{array}$ \\
\hline 1 & 1 & $\begin{array}{c}982.8(\mathrm{M})^{+} \\
\text {TAG bearing } 1 \mathrm{C}=\mathrm{C})+\mathrm{OH}+\text { grafted ME }\end{array}$ \\
\hline 4 & 0 & $900.4(\mathrm{M})^{+}(\mathrm{TAG}$ bearing $4 \mathrm{C}=\mathrm{C}+\mathrm{OH})$ \\
\hline 3 & 0 & $898.8(\mathrm{M})^{+}(\mathrm{TAG}$ bearing $3 \mathrm{C}=\mathrm{C}+\mathrm{OH})$
\end{tabular}

\section{Synthesis of lipidicmacroinitiators}

The alcohol groups of HMO or HGSO were used for the synthesis 80 of a lipidicmacroinitiator for the polymerization of MOx by cationic ring-opening polymerization (CROP). Generally, efficient initiators must have good leaving groups with appropriate nucleophilicity ${ }^{61}$ such as Lewis acids, strong protic acids and their corresponding esters, alkylhalides ${ }^{61}$, molecular iodine ${ }^{62}$ and rarely metallocenes ${ }^{63}$. ${ }_{5}$ The chemical structure of the initiator has an influence on the initiation and the propagation steps during the CROP. If the counteranion coming from the initiator is more nucleophilic than the monomer, a covalent mechanism occurs while in other cases, the mechanism proceeds as a ionic one ${ }^{61,64}$. In the case of 
polymerization of MOx, the nucleophilicity of this monomer is higher than that of counter-anion of the different possible types of initiator $\left(\mathrm{I}_{2}{ }^{62}, \mathrm{R}-\mathrm{I}\right.$, ROTs and ROTf). Consequently, only the ionic mechanism occurred during the CROP of MOx. The type of initiator 5 has also an influence on the conversion rate and it has been already shown that the covalent mechanism induced very low monomer conversion ${ }^{65}$ unlikethe ionic polymerizationprocess. Themacroinitiators were classified depending on the reaction rate ${ }^{66}$ : MeOTf $>$ MeOTs $>$ MeI $>$ benzyl bromide.

10 In this work, the synthesis of three kinds of lipidic initiators based on sulfonate esters coming from $p$-toluenesulfonyl chloride $(\mathrm{TsCl})$ or trifluoromethanesulfonic anhydride $\left(\mathrm{Tf}_{2} \mathrm{O}\right)$ and chloroacetyl chloride was investigated (Scheme 2).

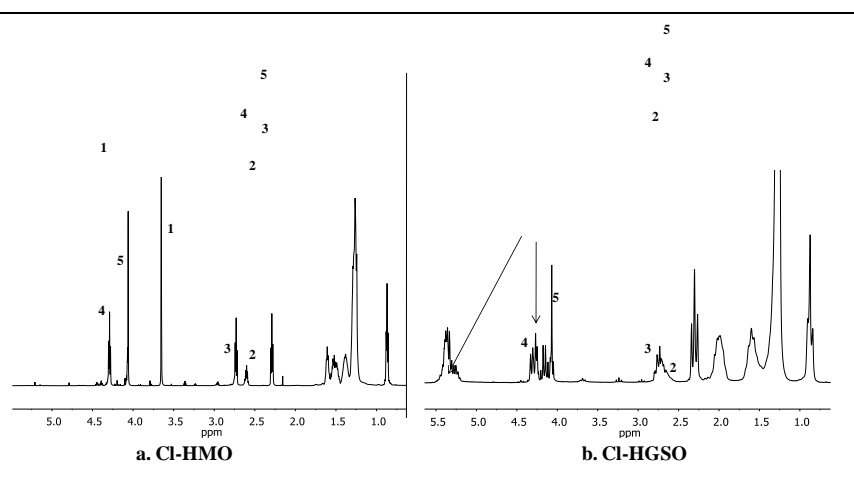

${ }_{50}$ Fig. ${ }^{1} \mathrm{H}$ NMR spectra of chloro-lipids (a. Cl-MO and b.Cl-GSO).

In summary, whatever the explored pathways, we assume that the addition of the reactants easily occurred on HMO and HGSO. But in the case of triflate and tosylate routes, the high reactivity of OTs and OTf species grafted onto the lipids rapidly induced rapidly side 55 reactions leading to the degradation of the lipidic-based reagent. This result is not surprising considering the strong electrophilicity of esters of trifluoromethanesulfonic and $p$-toluenesulfonic acids. On the contrary, the reactivity of $\mathrm{R}-\mathrm{Cl}$ reactant is low enough to ensure the stability of the macroinitiator. Thus, the strategy using CAC was

60 successfully extended to GSO with $93 \%$ yield. No degradation of the glycerol part was observed in the ${ }^{1} \mathrm{H}$ NMR spectrum with no change of the characteristic peaks between 4.2 and 4.4 and $5.2 \mathrm{ppm}$ (Figure 2b).

Scheme 2Different pathways for the synthesis of lipidicmacroinitiators.

Firstly the synthesis involving $\mathrm{TsCl}$ was tested and an amine was added to the mixture to trap chlorhydric acid molecules generated 20 during the reaction. The chemical structure of the amine can have an effect on conversion rate and we have to keep in mind that lipids are also sensitive to basic species (through the ester functions). Then the concentration and the nature of the added amine (triethylamine, pyridine and benzyldimethylamine) were studied. In all cases, after 25 proper purification, the expected macroinitiator was not isolated: new peaks at lower chemical shifts than the predictable ones were observed on ${ }^{1} \mathrm{H}$ NMR spectra (supporting information). Besides, the $\mathrm{M}_{\mathrm{w}}(514.8 \mathrm{~g} / \mathrm{mol})$ of the expected molecule was not observed in the LC-MS analysis.

30 The synthesis of the homologous triflatelipidicmacroinitiator was performed in the presence of $\mathrm{Tf}_{2} \mathrm{O}$ at $-20^{\circ} \mathrm{C}$. Similarly, the resulting product was not the expected one (no peak at $506.3 \mathrm{~g} / \mathrm{mol}$ was observed in LC-MS analysis). The ${ }^{1} \mathrm{H}$ NMR spectrum (supporting information) revealed that the characteristic peak of $\mathrm{CH}-\mathrm{S}$ on the

35 lipidic backbone disappeared suggesting a degradation of the hydroxylated lipids.

The synthesis of halogenated macroinitiators (Cl-lipids containing $\mathrm{Cl}-\mathrm{MO}$ and $\mathrm{Cl}-\mathrm{GSO}$ ) involved the reaction between the precursors bearing an alcohol function (HMO and HGSO) and chloroacetyl 40 chloride (CAC). The expected macroinitiators were successfully isolated in a $90 \%$ yield and identified by ${ }^{1} \mathrm{H}$ NMR (Figure 2a). The characteristic peak related to $\mathrm{CH}_{2}-\mathrm{OH}$ at $3.7 \mathrm{ppm}$ disappeared and the characteristic peaks related to $\mathrm{CH}_{2}-\mathrm{O}-\mathrm{C}=\mathrm{O}(\mathrm{t})(\mathrm{H}-4)$ and $\mathrm{CH}_{2}-$ $\mathrm{Cl}(\mathrm{s})$ (H-5) appeared at 4.3 and at $4.06 \mathrm{ppm}$, respectively. FTIR 45 analysis confirmed the disappearance of the large peak at $3400 \mathrm{~cm}^{-}$

${ }^{1}(\mathrm{OH})$, the increase of characteristic vibrations of ester group at 1736 and $1159 \mathrm{~cm}^{-1}$ and the appearance of a C-Cl vibration at 775 $\mathrm{cm}^{-1}$.

\section{${ }_{65}$ III Cationic ring-opening polymerization of MOx using lipidicmacroinitiators}

As previously mentioned, chlorinated compounds initiated the CROP of oxazoline monomer but induced very low monomer conversion. To improve the reactivity of chlorinated initiators, an in 70 situ conversion into iodide initiator was considered. In this case, the initiation step occurred in two stages: first, the trans-halogenation to convert $\mathrm{CH}_{2}-\mathrm{Cl}$ into $\mathrm{CH}_{2}-\mathrm{I}$ and then the initiation of polymerization. $\mathrm{CH}_{2}$-I exhibits a weak bondable to initiate the polymerization by an ionic mechanism via an oxazolinium species with $\mathrm{I}^{-}$as counter75 anion (Scheme 3). The living nature of the CROP implies the use of terminating agents such as amines to stop the growth of the polyoxazoline chains. Piperidine is an appropriate terminating agent since it is a good nucleophile and a mild basic compound which should not damage the glycerol part. In our case, it has been ${ }_{80}$ previously checked that piperidine could not react with ester group by trans-amination despite its $\mathrm{pK}_{\mathrm{a}}$ of 11.2.

Scheme 3CROP mechanism of MOx using Cl-MO or Cl-GSO.

\section{Study of the trans-halogenation}

The use of chlorinated macroinitiator combined with a iodide salt (NaI or $\mathrm{KI}$ ) has been already described in several studies ${ }^{65 a, 67}$. Uyamaet $a l .{ }^{68}$ showed that the kinetics of polymerization initiated 
by a chlorinated initiator in the presence of $\mathrm{NaI}$ was quite similar to a polymerization directly initiated by iodinated compounds. A short study of the trans-halogenation for equimolar ratio of $\mathrm{NaI}$ and $\mathrm{Cl}$ lipids was achieved. First the reaction was performed at room 5 temperature and monitored by ${ }^{1} \mathrm{H}$ NMR spectroscopy during $2 \mathrm{hrs}$. The lowering of the characteristic peak of $\mathrm{CH}_{2}-\mathrm{Cl}$ at $4.06 \mathrm{ppm}(\mathrm{H}-5)$ and the appearance of the characteristic peak of $\mathrm{CH}_{2}-\mathrm{I}$ at $3.7 \mathrm{ppm}$ (H-5') were followed and the conversion rate was evaluated by equation 3:

10

$\%$ iodine initiator $=\frac{\int 3.7 \mathrm{ppm}}{\int 3.7 \mathrm{ppm}+4.1 \mathrm{ppm}}$

No degradation of the lipidic structure was observed and the characteristic peak of $\mathrm{CH}_{3}-\mathrm{O}-\mathrm{C}=\mathrm{O}$ at $3.6 \mathrm{ppm}$, $(\mathrm{H}-1$, Figure 3) of 15 the ester function remained unchanged.
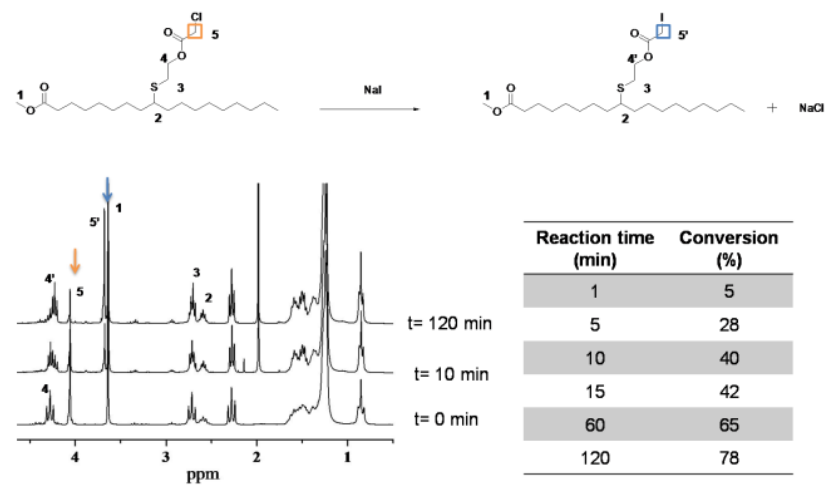

\begin{tabular}{cc}
\hline $\begin{array}{c}\text { Reaction time } \\
\text { (min) }\end{array}$ & $\begin{array}{c}\text { Conversion } \\
(\%)\end{array}$ \\
\hline 1 & 5 \\
5 & 28 \\
10 & 40 \\
15 & 42 \\
60 & 65 \\
120 & 78 \\
\hline
\end{tabular}

Fig.3Study of the trans-halogenation on the fatty ester macroinitiatorCl-MO.

20 After 15 min, $42 \%$ of chloride was exchanged with iodide and 2 hrs was required to reach a maximum of conversion with a percentage of trans-halogenation close to $80 \%$. At room temperature, the transhalogenation reaction is slow. Therefore the same experiment was performed at $80^{\circ} \mathrm{C}$ and complete reaction was observed after 5 25 minutes. As a consequence, the polymerization step was performed with a chlorinated macroinitiator in the presence of $\mathrm{NaI}$ at $80^{\circ} \mathrm{C}$ after waiting $5 \mathrm{~min}$ to insure complete trans-halogenation.

\section{Study of the CROP of MOx}

${ }_{30}$ The CROP of MOx was performed in the presence of two lipidicmacroinitiators: a fatty ester (Cl-MO) and the modified triglyceride (Cl-GSO). The resulting amphiphilic polymers based on polyoxazoline $\left(\mathrm{MO}-\mathrm{POx}_{\mathrm{n}}\right.$ and GSO-POx ${ }_{\mathrm{n}}$ ) were synthesized with theoretical degrees of polymerization ranging from 8 to 50 . The 35 yields ranged from 15 to $86 \%$ depending on the length of polyoxazoline chains. The apparent degree of polymerization of polyoxazoline were calculated using equation 4 :

$$
\text { DPn, app }=\frac{\mathrm{M}_{\mathrm{n}(\mathrm{SEC})}-\mathrm{M}_{\text {Macroinitiator }}-\mathrm{M}_{\text {Termination }} \quad \text { agent }}{\mathrm{M}_{\text {monomer }}}
$$

40

withM $_{n}$ (SEC) determined by SEC (Figure 4, left). For both macroinitiators (Cl-GSO and $\mathrm{Cl}-\mathrm{MO}$ ), the experimental apparent degrees of polymerization ranged from 11 to 56 . The polydispersity indexes $(Đ)$ ranging from 1.1 to 1.3 for $\mathrm{MO}-\mathrm{POx}_{\mathrm{n}}$ and from 1.2 to

451.5 for GSO-POx ${ }_{n}$ are usual values in the case of initiation involving a halogenated species ${ }^{28}$. The evolution of $\mathrm{M}_{\mathrm{n}}$ versus $\left([\mathrm{M}]_{0} /[\mathrm{I}]_{\text {trans }}\right)$ in the case of $\mathrm{MO}-\mathrm{POx}_{\mathrm{n}}$ is represented in Figure 4 , with $[\mathrm{M}]_{0}$ the monomer concentration at $\mathrm{t}=0$ and $[\mathrm{I}]_{\text {trans }}$ the initiator concentration after trans-halogenation. The linear evolution indicated the absence 50 of substantial transfer reactions during the polymerization. This result is generally observed with common initiators but was never reported with initiators exhibiting relatively high molecular weights such as bio-based compounds derived from natural oils. In the case of triglyceride-based macroinitiators, polydispersity indexes (Đ) 55 were quite good considering that commercial crude oil was directly used. The gap between theoretical and experimental $\mathrm{M}_{\mathrm{n}}$ maycorrespond to a partial efficiency of the macroinitiator.

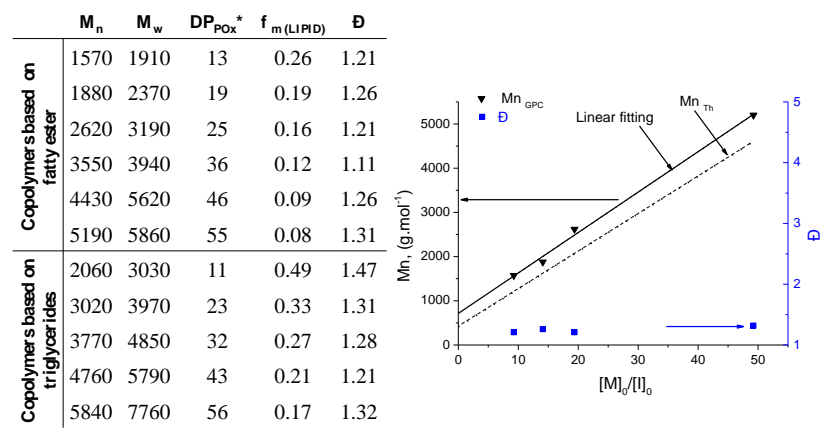

Fig. 4 Molecular weights and polydispersity indexes for the 60 polymerization of 2-methyl-2-oxazoline initiated by fatty ester- or triglyceride-based initiators (left). Evolution of $M_{n}$ and

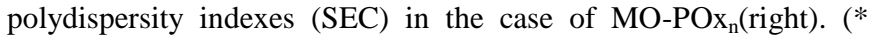
experimental value measured by SEC in DMF).

The copolymersystems were also characterized by ${ }^{1} \mathrm{H}$ NMR ${ }_{65}$ spectroscopy and the superposition of NMR spectra of Cl-MO and $\mathrm{MO}-\mathrm{POx}_{\mathrm{n}}$ is given in Figure 5. In the $\mathrm{MO}-\mathrm{POx}_{\mathrm{n}}$ spectrum, the typical peaks of the lipidic part were observed at $3.67 \mathrm{ppm}$ for $\mathrm{CH}_{3}-$ $\mathrm{O}-\mathrm{C}=\mathrm{O}$ (methyl ester group $(\mathrm{H}-1)), 2.3 \mathrm{ppm}$ for $\mathrm{CH}_{2}-\mathrm{C}=\mathrm{O}(\mathrm{H}-2)$ and $0.88 \mathrm{ppm}$ for terminal $\mathrm{CH}_{3}(\mathrm{H}-3)$. Moreover, the disappearance of 70 the peak at $4.06 \mathrm{ppm}$ characteristic of $\mathrm{CH}_{2}-\mathrm{Cl}$ group, the appearance of new peaks at $4.1 \mathrm{ppm}$ corresponding to $(\mathrm{C}=\mathrm{O})-\mathrm{CH}_{2}-\mathrm{N}(\mathrm{H}-7)$ and peaks belonging to the $\mathrm{POx}$ chains at 1.9-2.1 ppm $\left(\mathrm{CH}_{3}(\mathrm{C}=\mathrm{O}), \mathrm{H}-\right.$ 10) and 3.4-3.6 ppm $\left(\mathrm{CH}_{2}-\mathrm{CH}_{2}, \mathrm{H}-8\right.$ andH-9) confirmed the simultaneous presence of POx and the fatty chain. The termination 75 with piperidine was found to be effective with the characteristic peaks at $3.15\left(\mathrm{~N}-\mathrm{CH}_{2}, \mathrm{H}-11\right), 1.88\left(\mathrm{~N}_{-} \mathrm{CH}_{2}-\mathrm{CH}_{2}, \mathrm{H}-12\right)$ and 1.67 ppm $\left(\mathrm{N}-\mathrm{CH}_{2}-\mathrm{CH}_{2}-\mathrm{CH}_{2}, \mathrm{H}-13\right)$. The degree of polymerization of LipoPOxbased on fatty ester wascalculatedusing the integration of the characteristicsignals of terminal $\mathrm{CH}_{3}$ of fattychainat $0.8 \mathrm{ppm}$ 80 related tothat of $\mathrm{CH}_{3}$ group of polyoxazoline unit at $2.2 \mathrm{ppm}$. The $\mathrm{DP}_{\mathrm{n}, \mathrm{NMR}}$ values in DMF were close to theoreticalones. For instance, $\mathrm{DP}_{\mathrm{n}, \mathrm{NMR}}$ of 10, 17 and 43werecalculatedinstead of 9.3, 14.1 and 49.2 theoretical valuesrespectively. Wenotedthat in Figure 5, $\mathrm{CDCl}_{3}$ wasprefered to $\mathrm{DMF}-\mathrm{d}_{6}$ as NMR solvent for a better 85 attribution of eachsignalsavoidingoverlaps. Moreover in the samesolvent (DMF), a good correlationbetweenDP ${ }_{n, N M R}$ and $\mathrm{DP}_{\mathrm{n}, \mathrm{SEC}}$ wasobservedwith a slightlyhigher values by SEC 13,19 and 55 instead of 10, 17 and 43 by NMR spectroscopy. 


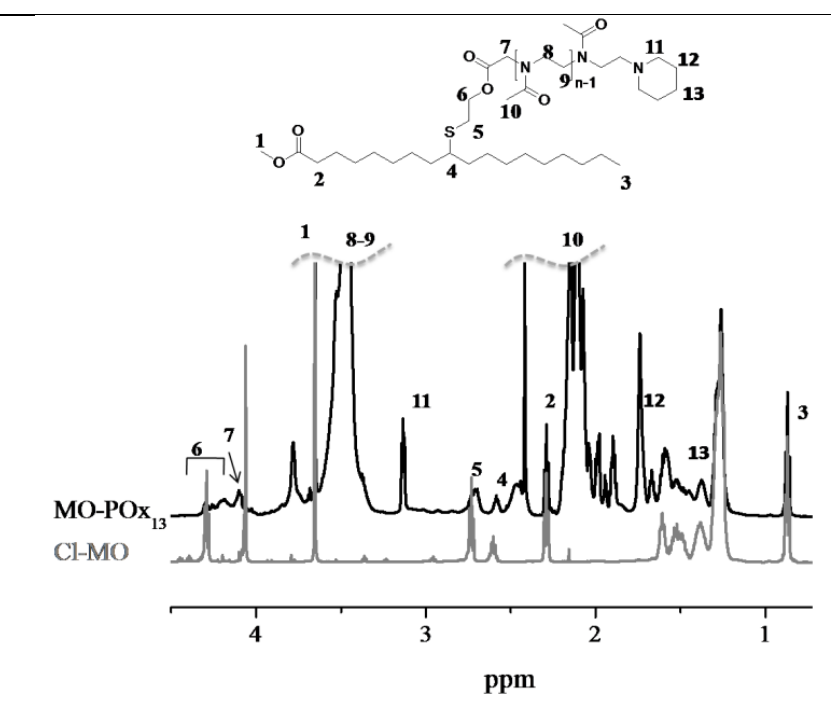

Fig. 5 Comparison of ${ }^{1} \mathrm{H}$ NMR spectra of $\mathrm{Cl}-\mathrm{MO}$ and $\mathrm{MO}-\mathrm{POx}_{13}$.

Otherwise, MO-POx samples were characterized by MALDI-Tof spectroscopy as illustrated in Figure 6 in the case of MO-POx 55 . 5 Three series of peaks were observed, each one showing a difference of mass $\Delta \mathrm{m}$ between two successive peaks of $85.05 \mathrm{~g} / \mathrm{mol}$ characteristic of the repetitive unit of POx. These series of peaks were ascribed to $\mathrm{MO}-\mathrm{POx}_{\mathrm{n}}$-piperidine/ $\mathrm{Na}^{+}$species, MO-POx $\mathrm{x}_{\mathrm{n}-1}-$ $\mathrm{NH}-\mathrm{CH}_{2}-\mathrm{CH}_{2}-\mathrm{OH} / \mathrm{Na}^{+}$hydroxylamine ${ }^{69}$ ones and $\mathrm{MO}-\mathrm{PO} \mathrm{x}_{\mathrm{n}}-\mathrm{OH} / \mathrm{Na}^{+}$ 10 hydroxyl terminated polymers.

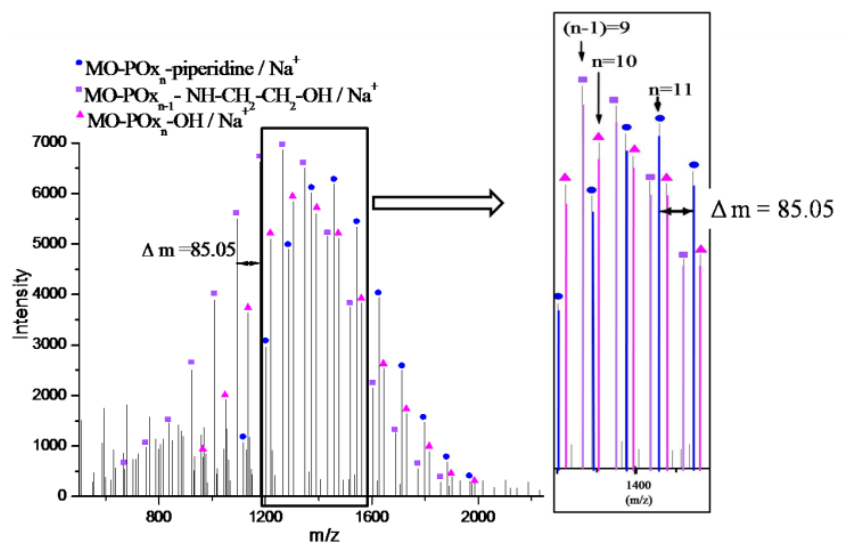

Fig. 6MALDI-Tof spectrum of MO-POx ${ }_{55}$.

All of the previous characterizations demonstrated the well-defined structure of $\mathrm{MO}-\mathrm{POx}_{\mathrm{n}}$ amphiphilic polymers with lipidic and 15 polyoxazoline parts associated in different ratios. Similar investigations were done in the case of polymers based on GSO$\mathrm{POx}_{\mathrm{n}} \cdot{ }^{1} \mathrm{H}$ NMR spectra confirmed the efficacious polymerization of MOx starting from the triglyceride-based Cl-GSO macroinitiator (supporting information). The Maldi-Tof spectrum revealed the $\Delta \mathrm{m}$ $20=85.05 \mathrm{~g} / \mathrm{mol}$ confirming the presence of the polyoxazoline chains even if the chain ends were too complicated to be ascribed. Size exclusion chromatography (SEC) analysis was performed and Figure 7 represents the trace in the case of the GSO-POx ${ }_{56}$ sample. The full black line allowed determining a molecular weight $M_{n}$ of ${ }_{25} 5840 \mathrm{~g} / \mathrm{mol}$ and $\mathrm{M}_{\mathrm{w}}$ of $7760 \mathrm{~g} / \mathrm{mol}$. Moreover a slight shoulder was observed at lower elution time. Deconvolution of the trace using two Gaussian functions revealed two populations of copolymers. Using the value of the elution time for the maximum of each peak, $M_{w}$ were calculated at $9700 \mathrm{~g} / \mathrm{mol}$ for the first peak and $6510 \mathrm{~g} / \mathrm{mol}$ for
30 the second one. Considering the gap between both $M_{w}$ values, lipopolymers with the highest $\mathrm{M}_{\mathrm{w}}$ could be ascribed to triglycerides bearing two POx chains. This result is not surprising since previous LC-MS analysis revealed the presence of some di-hydroxylated triglycerides in minor quantity.

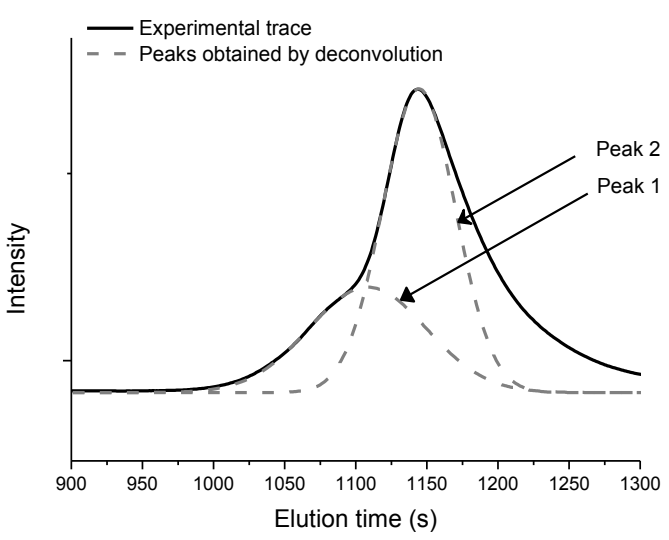

Fig. 7Deconvolution of SEC trace for GSO-POx 56 using two Gaussian functions.

At last, the lipidic mass fraction $f$ (molecular mass of the lipid part 40 divided by the $\mathrm{M}_{\mathrm{n}}$ of LipoPOx polymer) indicating the lipophilic character was evaluated (Figure 4). franging from 0.8 to 0.26 for MO-POx ${ }_{n}$ and from 0.17 to 0.49 for GSO-POx $x_{n}$ were obtained. This wide range shows the possibility to produce various amphiphilic polymers with tunable lipophilic / hydrophilic balance.

45

\section{Self-assembly of LipoPOx copolymers in water}

Voletet al. $^{31}$ already showed that strictly linear LipoPOx were able to self-assemble in water. In the present systems, polymers based on lipids and polyoxazoline led to different architectures where grafted 50 POx chains were inserted in the middle of the lipidic chains. Thus the ability of self-organization in aqueous medium was investigated by the dynamic light scattering (DLS) technique for the two structures of lipopolymers: MO-POx $n$ and GSO-POx $n$ with a POx length of respectively $13\left(\mathrm{MO}-\mathrm{POx}_{13}\right)$ and $11\left(\mathrm{GSO}-\mathrm{POx}_{11}\right)$ units as 55 determined by SEC. From the DLS experiments, the autocorrelation functions $\left(g^{(2)}-1\right)$ and the relaxation time distributions measured in both systems at 40,90 and $140^{\circ}$ are shown in Figure $8 \mathrm{a}$ and $8 \mathrm{~b}$. Whatever the scattering angle, the measurements exhibit single exponential decay autocorrelation functions, and monomodal 60 narrow relaxation time distributions. At a given scattering angle, the relaxation time $(1 / \Gamma)$ is given by theposition of the maximum value of the autocorrelation function along thex-axis. The linear dependences of the relaxation frequency $(\Gamma)$ on the square of the wave vector modulus $\left(\mathrm{q}^{2}\right)$ clearly indicate the Brownian diffusive 65 motion of particles in both cases (Figures 8c and 8d). The value of the slope is equal to the diffusion coefficient (D) of the particles from which the hydrodynamic radius $\left(\mathrm{R}_{\mathrm{H}}\right)$ is calculated for each sample using the Stokes-Einstein relation $R_{H}=\frac{k_{B} T}{6 \pi \eta D}$ where $\mathrm{k}_{\mathrm{B}}$ is the Boltzmann constant, $\mathrm{T}$ represents the absolute temperature of the 70 sample and $\eta$ is the viscosity of the pure solvent (water in this case $)^{70}$. The calculated values of $\mathrm{R}_{\mathrm{H}}$ are 4.3 and $10.2 \mathrm{~nm}$ for MO$\mathrm{POx}_{13}$ and GSO-POx 11 , respectively ${ }^{71}$. Indeed, whatever the scattering angle, the relaxation time for $\mathrm{GSO}-\mathrm{POx}_{11}$ is higher than that for $\mathrm{MO}-\mathrm{POx}_{13}$, reflecting the lower diffusion coefficient 75 calculated for GSO-POx 11 . The two values of $\mathrm{R}_{\mathrm{H}}$ differ by a factor of more than two. This behavior can be reasonably attributed to the fact that GSO-POx ${ }_{11}$ (based on triglyceride) presents a more massive lipidic part than $\mathrm{MO}-\mathrm{POx}_{13}$ (based on fatty ester). The lipidic fractions represent $49.0 \%$ versus $26.0 \%$ in weight which promotes 
hydrophobic interactions and drives the self-assembly process in water towards the formation of bigger nanoparticles so that the stabilization by the hydrophilic block (i.e. POx) can be readily achieved. No supra-aggregates or uncontrolled self-assemblies could 5 be detected. Moreover, although SEC analysis revealed the presence of two size distributions, as shown in Figure 7 with the example of GSO-POx ${ }_{56}$, the formed nanoparticles of GSO-POx 11 , presenting one peak at $\mathrm{M}_{\mathrm{w}}=4160 \mathrm{~g} / \mathrm{mol}$ and another at $\mathrm{M}_{\mathrm{w}}=2510 \mathrm{~g} / \mathrm{mol}$, remain surprisingly monomodal and quite monodisperse in size, as 10 observed for $\mathrm{MO}-\mathrm{POx}_{13}$. No other peak is present in the relaxation time distribution. The self-assembly is thus not affected by the presence of the minor product. As a consequence, the fatty esterand triglyceride-based LipoPOx self-assemble in monomodal quite monodisperse nanoparticles, forming nano-objects. The self15 assembly of these lipopolymers is still under investigation and will be reported in a forthcomingarticle.
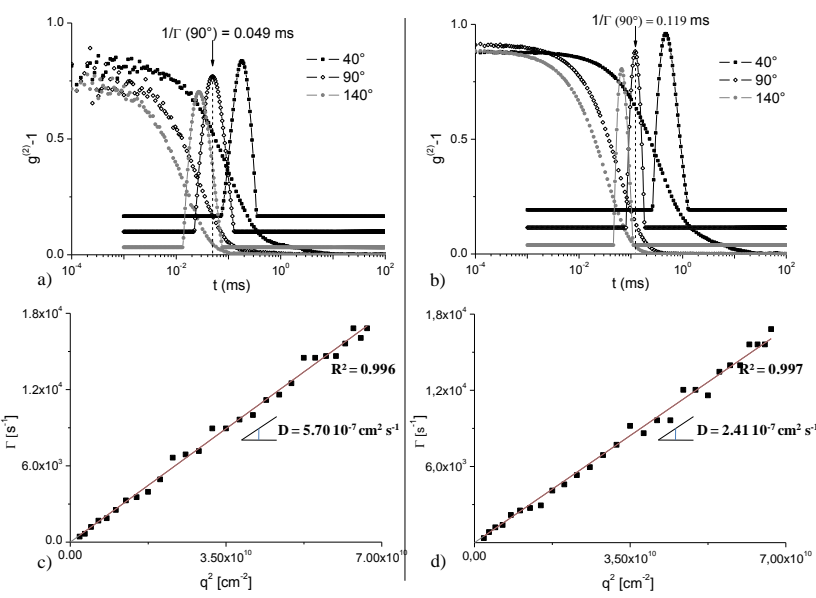

Fig. 8DLS results of $\mathrm{MO}-\mathrm{POx}_{13}(\mathrm{C}=2$ g/L) (a: autocorrelation function $\left(\mathrm{g}^{(2)}-1\right)$ and relaxation time distribution curve, $\mathrm{c}$ : 20 dependence of the relaxation frequency $(\Gamma)$ on the square of the wave vector modulus $\left(\mathrm{q}^{2}\right)$ ) and GSO-POx 11 (b: autocorrelation function $\left(\mathrm{g}^{(2)}-1\right)$ and relaxation time distribution curve, $\mathrm{d}$ : dependence of the relaxation frequency $(\Gamma)$ on the square of the wave vector modulus $\left(\mathrm{q}^{2}\right)$ ).

\section{${ }_{25}$ Conclusions}

We report here an original synthesis of lipopolymers based on lipids and poly(2-methyl-2-oxazoline). Common vegetable crude oil was modified to make it reactive and used as the macroinitiator for the cationic ring-opening polymerization of the oxazoline monomer.

30 The modification of the double bonds of lipids via soft thiol-ene chemistry allowed the synthesis of a halogenated macroinitiator. This macroinitiator leads to very good control of the polymerization of the 2-methyl-2-oxazoline with polydispersity index inferior to 1.5. Despite the complexity of the composition of crude oil and 35 well-known drastic conditions required by a cationic type polymerization, we succeeded in the obtaining of amphiphilic polymers with a good composition control. The lipopolymers based on fatty esters and vegetable oils were shown to self-organize into nano-objects in aqueous medium without formation of any supra-

40 aggregates or uncontrolled self-assembly. Well-shaped nanoparticles were obtained with characteristic radii of about4.3 and $10.2 \mathrm{~nm}$ for the fatty ester- and triglyceride-based LipoPOx, respectively. Their relaxation time distributions were monomodal and highlymonodisperse.

\section{${ }_{45}$ Acknowledgements}

The authors are thankful to Prof. R. Pecora for helpful discussions and to the Région Languedoc-Roussillon and CNRS for their financial support (BG). G. Cazals, G. Valette and A. Lebrun from UM2 are acknowledged for their technical assistance.

\section{${ }_{50}$ Notes and references}

${ }^{a}$ Institut Charles Gerhardt Montpellier UMR5253 CNRS-UM2-ENSCM-UM1 - Equipe Ingénierie et ArchitecturesMacromoléculaires, Université Montpellier II cc1702, Place EugèneBataillon, 34095 Montpellier, France. E-mail: vincent.lapinte@univ-montp2.fr; Fax: +33-467144028; Tel: +3355467144832

${ }^{b}$ Centre de Recherches sur les Macromolécules Végétales CERMAV UPR5301 CNRS-UJF, Member of the Institut de Chimie Moléculaire de Grenoble and Member of the PolyNat Carnot Institute, Domaine Universitaire de Grenoble, 601 rue de la Chimie, BP 53, 38041 Grenoble 60 cedex 9 , France

$\uparrow$ Electronic Supplementary Information (ESI) available: [details of any supplementary information available should be included here]. See DOI: $10.1039 / \mathrm{b} 000000 \mathrm{x} /$

1 Eissen, M.; Metzger, J. O.; Schmidt, E.; Schneidewind, U. Angewandte Chemie International Edition 2002, 41, 414.

2 Gandini, A. Macromolecules 2008, 41, 9491.

3 Yu, L.; Dean, K.; Li, L. Progress in Polymer Science 2006, 31, 576.

704 Vieira, M. G. A.; da Silva, M. A.; dos Santos, L. O.; Beppu, M. M. European Polymer Journal 2011, 47, 254.

5 Derksen, J. T. P.; Petrus Cuperus, F.; Kolster, P. Progress in Organic Coatings 1996, 27, 45.

6 Alexandridis, P. Current Opinion in Colloid \&amp; Interface Science 1996, 1, 490

7 Discher, D. E.; Eisenberg, A. Science 2002, 297, 967.

8 Discher, B. M.; Won, Y.-Y.; Ege, D. S.; Lee, J. C.-M.; Bates, F. S.; Discher, D. E.; Hammer, D. A. Science 1999, 284, 1143.

9 Lim, H.; Kassim, A.; Huang, N.; Ambar Yarmo, M. Journal of Surfactants and Detergents 2009, 12, 355.

10 Qiu, L.; Bae, Y. Pharmaceutical Research 2006, 23, 1.

11 (a) Von Rybinski, W.; Hill, K. Angewandte Chemie International Edition 1998, 37, 1328; (b) Boyer, A.; Lingome, C. E.; Condassamy, O.; Schappacher, M.; Moebs-Sanchez, S.; Queneau, Y.; Gadenne, B.; Alfos, C.; Cramail, H. Polymer Chemistry 2012.DOI: 10.1039/C2PY20588B

12 Gissot, A.; Camplo, M.; Grinstaff, M. W.; Barthelemy, P. Organic \& Biomolecular Chemistry 2008, 6, 1324.

13 Schatz, C.; Louguet, S.; Le Meins, J.-F.; Lecommandoux, S. Angewandte Chemie International Edition 2009, 48, 2572.

9014 de Medeiros Modolon, S.; Otsuka, I.; Fort, S.; Minatti, E.; Borsali, R.; Halila, S. Biomacromolecules 2012, 13, 1129.

15 (a) Otsuka, I.; Travelet, C.; Halila, S.; Fort, S.; Pignot-Paintrand, I.; Narumi, A.; Borsali, R. Biomacromolecules 2012, 13, 1458; (b) Otsuka, I.; Fuchise, K.; Halila, S.; Fort, S. b.; Aissou, K.; Pignot-Paintrand, I.; Chen, Y.; Narumi, A.; Kakuchi, T.; Borsali, R. Langmuir 2010, 26, 2325 (c) Aissou, K.; Otsuka, I.; Rochas, C.; Fort, S. b.; Halila, S.; Borsali, R. Langmuir 2011, 27, 4098.

16 Lowik, D. W. P. M.; van Hest, J. C. M. Chemical Society Reviews 2004, 33, 234.

10017 Johansson, I.; Svensson, M. Current Opinion in Colloid \&amp; Interface Science 2001, 6, 178.

18 Xu, Q.; Liu, Z.; Nakajima, M.; Ichikawa, S.; Nakamura, N.; Roy, P.; Okadome, H.; Shiina, T. Bioresource Technology 2010, 101, 3711.

19 Svensson, M. In Surfactants from Renewable Resources; John Wiley \& Sons, Ltd, 2010.

20 Hoogenboom, R. European Journal of Lipid Science and Technology 2011, 113, 59 .

21 Hoogenboom, R. Angewandte Chemie International Edition 2009, 48, 7978.

1022 Guillerm, B.; Monge, S.; Lapinte, V.; Robin, J.-J. Macromolecular Rapid Communications 2012, 33, 19, 1600-1612.

23 (a) Einzmann, M.; Binder, W. H. Journal of Polymer Science Part A: Polymer Chemistry 2001, 39, 2821; (b) Luxenhofer, R.; Sahay, G.; Schulz, A.; Alakhova, D.; Bronich, T. K.; Jordan, R.; Kabanov, A. V. 115 Journal of Controlled Release 2011, 153, 73.

24 Fruijtier-Pölloth, C. Toxicology 2005, 214, 1. 
25 (a) Knop, K.; Hoogenboom, R.; Fischer, D.; Schubert, U. S. Angewandte Chemie International Edition 2010, 49, 6288; (b) Tong, J.; Luxenhofer, R.; Yi, X.; Jordan, R.; Kabanov, A. V. Molecular Pharmaceutics 2010, 7, 984; (c) Adams, N.; Schubert, U. S. Advanced Drug Delivery Reviews 2007, 59, 1504.

26 olet, G.; Chanthavong, V.; Wintgens, V.; Amiel, C. Macromolecules 2005, 38, 5190.

27 Kobayashi, S.; Uyama, H.; Higuchi, N.; Saegusa, T. Macromolecules 1990, 23, 54

1028 Einzmann, M.; Binder, W. H. J. Polym. Sci., Part A: Polym. Chem. 85 2001, 39, 2821.

29 Jordan, R.; Martin, K.; Räder, H. J.; Unger, K. K. Macromolecules 2001, 34, 8858

30 Giardi, C.; Lapinte, V.; Charnay, C.; Robin, J. J. Reactive and Functional Polymers 2009, 69, 643.

31 Volet, G.; Auvray, L.; Amiel, C. J. Phys. Chem. B 2009, 113, 13536.

32 (a) Bodycomb, J.; Hara, M. Macromolecules 1995, 28, 8190; (b) Provencher, S. W. Die Makromolekulare Chemie 1979, 180, 201.

33 (a) Sutton, D.; Johnson, N.; Hlongwane, C.; Ayorinde, F. Journal of the American Oil Chemists' Society 2009, 86, 675; (b) Yoshida, Y.; Sakakura, Y.; Aso, N.; Okada, S.; Tanabe, Y. Tetrahedron 1999, 55, 2183; (c) Hsu, C. S.; Shih, L. J.; Hsiue, G. H. Macromolecules 1993, 26, 3161; (d) Morita, J.-i.; Nakatsuji, H.; Misaki, T.; Tanabe, Y. Green Chemistry 2005, 7, 711.

2534 Harris, J. M.; Bentley, M. D.; Yoon, K.; Reif, M.; Jordan, R.; Serina 100 Therapeutics, Inc., USA . 2010

35 Wiesbrock, F.; Hoogenboom, R.; Leenen, M. A. M.; Meier, M. A. R.; Schubert, U. S. Macromolecules 2005, 38, 5025.

36 (a) Raquez, J. M.; Deléglise, M.; Lacrampe, M. F.; Krawczak, P.

$30 \quad$ Progress in Polymer Science 2010, 35, 487; (b) Rüsch gen. Klaas, M.; 105 Warwel, S. Industrial Crops and Products 1999, 9, 125.

37 Sitaramam, B. S.; Chatterjee, P. C.; Sivasamban, M. A. Paintindia 1986, 36, 17.

38 Paramarta, A.; Pan, X.; Webster, D. C. Polymeric Preprints (American

35 Chemical Society, Division of Polymer Chem stry) 2011, 52 (1), 552.

39 de Espinosa, L. M.; Ronda, J. C.; Galià, M.; Cádiz, V. Journal of Polymer Science Part A: Polymer Chemistry 2009, 47, 1159.

40 Mahendran, A. R.; Aust, N.; Wuzella, G.; Kandelbauer, A. Macromolecular Symposia 2012, 311, 18.

4041 Okieimen, F. E.; Pavithran, C.; Bakare, I. O. European Journal of Lipid 11567 Science and Technology 2005, 107, 330.

42 Petrović, Z. S.; Zhang, W.; Javni, I. Biomacromolecules 2005, 6, 713.

43 Ionescu, M.; Petrovic, Z. S. J. Serb. Chem. Soc. 2011, 76, 591.

44 Eren, T.; Küsefoğlu, S. H. Journal of Applied Polymer Science 2004, 91, 4037.

45 Desroches, M.; Caillol, S.; Lapinte, V.; Auvergne, R. m.; Boutevin, B. Macromolecules 2011, 44, 2489.

46 Kolb, H. C.; Finn, M. G.; Sharpless, K. B. Angewandte Chemie International Edition 2001, 40, 2004.

5047 Hoyle, C. E.; Lee, T. Y.; Roper, T. Journal of Polymer Science Part A: 12570 Polymer Chemistry 2004, 42, 5301

48 Vaughan, W. E.; Rust, F. F. The Journal of Organic Chemistry 1942, 7, 472.

49 Walling, C.; Helmreich, W. Journal of the American Chemical Society $1959, \mathbf{8 1}, 1144$.

50 Wutticharoenwong, K.: Soucek, M. D. Macromolecular Materials and Engineering 2008, 293, 45.

51 Roper, T. M.; Guymon, C. A.; Jönsson, E. S.; Hoyle, C. E. Journal of Polymer Science Part A: Polymer Chemistry 2004, 42, 6283.

6052 Uygun, M.; Tasdelen, M. A.; Yagci, Y. Macromolecular Chemistry and Physics 2010, 211, 103.

53 Cramer, N. B.; Reddy, S. K.; Cole, M.; Hoyle, C.; Bowman, C. N. Journal of Polymer Science Part A: Polymer Chemistry 2004, 42, 5817.

54 Scott, T. F.; Kloxin, C. J.; Draughon, R. B.; Bowman, C. N. Macromolecules 2008, 41, 2987.

55 (a) Bexell, U.; Berger, R.; Olsson, M.; Grehk, T. M.; Sundell, P. E.; Johansson, M. Thin Solid Films 2006, 515, 838; (b) Chatgilialoglu, C.; Altieri, A.; Fischer, H. Journal of the American Chemical Society 2002, 124, 12816; (c) Chatgilialoglu, C.; Samadi, A.; Guerra, M.; Fischer, H. ChemPhysChem 2005, 6, 286; (d) Bantchev, G. B.; Kenar, J. A.; Biresaw, G.; Han, M. G. Journal of Agricultural and Food Chemistry 2009, 57, 1282; (e) Cramail, H.; Boyer, A.; Cloutet, E.; Alfos, C.; WO2011045536A1, 2011; (f) More, A. S.; Gadenne, B.; Alfos, C.; Cramail, H. Polym. Chem. 2012, 3, 1594; (g) Palaskar, D. V.; Boyer, A.; Cloutet, E.; Le, M. J.-F.; Gadenne, B.; Alfos, C.; Farcet, C.; Cramail, H.
J. Polym. Sci., Part A: Polym. Chem. 2012, 50, 1766; (h) González-Paz, R. J.; Lluch, C.; Lligadas, G.; Ronda, J. C.; Galià, M.; Cádiz, V. Journal of Polymer Science Part A: Polymer Chemistry 2011, 49, 2407; (i) Samuelsson, J.; Jonsson, M.; Brinck, T.; Johansson, M. Journal of Polymer Science Part A: Polymer Chemistry 2004, 42, 6346; (j) Schwab, A.; Gast, L. Journal of the American Oil Chemists' Society 1970, 47, 371; (k) Stemmelen, M.; Pessel, F.; Lapinte, V.; Caillol, S.; Habas, J. P.; Robin, J. J. Journal of Polymer Science Part A: Polymer Chemistry 2011, 49, 2434; (1) Türünç, O.; Meier, M. A. R. Macromolecular Rapid Communications 2010, 31, 1822.

56 Samadi, A.; Andreu, I.; Ferreri, C.; Dellonte, S.; Chatgilialoglu, C. Journal of the American Oil Chemists' Society 2004, 81, 753.

57 (a) Guo, A.; Cho, Y.; Petrović, Z. S. Journal of Polymer Science Part A: Polymer Chemistry 2000, 38, 3900; (b) Dahlke, B.; Hellbardt, S.; Paetow, M.; Zech, W. Journal of the American Oil Chemists' Society 1995, 72, 349; (c) Petrovic, Z. Contemporary Materials 2010, I, 39; (d) Köckritz, A.; Martin, A. European Journal of Lipid Science and Technology 2008, 110, 812.

58 Boileau, S.; Mazeaud-Henri, B.; Blackborow, R. European Polymer Journal 2003, 39, 1395.

59 Black, M.; Rawlins, J. W. European Polymer Journal 2009, 45, 1433

60 Lucas, P.; Fleury, E.; Estur, J.-F.; Lapinte, V.; Robin, J.-J. Macromolecular Chemistry and Physics 2009, 210, 1933.

61 Aoi, K.; Okada, M. Progress in Polymer Science 1996, 21, 151.

62 Guillerm, B.; Monge, S.; Lapinte, V.; Robin, J.-J. Macromolecules 2010, 43, 5964.

63 Kourti, M.-E.; Vougioukalakis, G. C.; Hadjichristidis, N.; Pitsikalis, M. Journal of Polymer Science Part A: Polymer Chemistry 2011, 49, 2520.

64 Dubois, P.; Coulembier, O.; Raquez, J.-M.; Editors Handbook of RingOpening Polymerization; Wiley-VCH Verlag GmbH \& Co. KGaA, 2009.

65 (a) Weberskirch, R.; Hettich, R.; Nuyken, O.; Schmaljohann, D.; Voit, B. Macromolecular Chemistry and Physics 1999, 200, 863; (b) Fijten, M. W. M.; Hoogenboom, R.; Schubert, U. S. Journal of Polymer Science Part A: Polymer Chemistry 2008, 46, 4804.

66 (a) Hoogenboom, R.; Fijten, M. W. M.; Schubert, U. S. Journal of Polymer Science Part A: Polymer Chemistry 2004, 42, 1830; (b) Paulus, R. M.; Becer, C. R.; Hoogenboom, R.; Schubert, U. S. Macromolecular Chemistry and Physics 2008, 209, 794.

(a) McAlvin, J. E.; Fraser, C. L. Macromolecules 1999, 32, 1341; (b) Rueda, J. C.; Komber, H.; Voit, B. Journal of Polymer Science Part A: Polymer Chemistry 2005, 43, 122; (c) Kim, K.-M.; Keum, D.-K.; Chujo, Y. Macromolecules 2003, 36, 867; (d) McAlvin, J. E.; Scott, S. B.; Fraser, C. L. Macromolecules 2000, 33, 6953; (e) Hoogenboom, R.; Fijten, M. W. M.; Schubert, U. S. Macromolecular Rapid Communications 2004, 25, 339.

68 Uyama, H.; Kobayashi, S. Macromolecules 1991, 24, 614.

69 Baumgaertel, A.; Weber, C.; Knop, K.; Crecelius, A.; Schubert, U. S. Rapid Communications in Mass Spectrometry 2009, 23, 756

0 (a) Dal Bó, A. G.; Soldi, V.; Giacomelli, F. C.; Travelet, C.; Jean, B.; Pignot-Paintrand, I.; Borsali, R.; Fort, S. Langmuir 2011, 28, 1418; (b) Arndt K.-F., M. G. Polymercharakterisierung; Hanser: Munich, 1996.

71 The hydrodynamic radius extrapolated from the angular dependency which is presently discussed should not be confused with the hydrodynamic radius at a given scattering angle. This latter value is just an apparent value. 